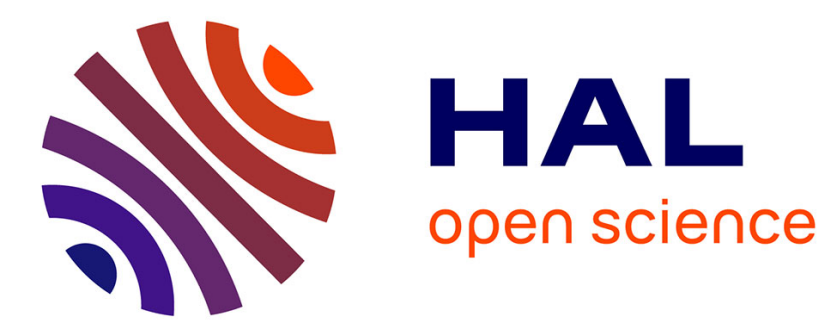

\title{
High-pressure experimental geosciences: state of the art and prospects
}

Chrystèle Sanloup

\section{To cite this version:}

Chrystèle Sanloup. High-pressure experimental geosciences: state of the art and prospects. Bulletin de la Société Géologique de France, 2012, 183 (3), pp.173-185. 10.2113/gssgfbull.183.3.175 . hal00707380

\section{HAL Id: hal-00707380 \\ https://hal.science/hal-00707380}

Submitted on 12 Jun 2012

HAL is a multi-disciplinary open access archive for the deposit and dissemination of scientific research documents, whether they are published or not. The documents may come from teaching and research institutions in France or abroad, or from public or private research centers.
L'archive ouverte pluridisciplinaire HAL, est destinée au dépôt et à la diffusion de documents scientifiques de niveau recherche, publiés ou non, émanant des établissements d'enseignement et de recherche français ou étrangers, des laboratoires publics ou privés. 


\title{
High-Pressure experimental geosciences: state of the art and prospects
}

\author{
CHRYSTÈLE SANLOUP
}

UPMC Univ Paris 06, UMR 7193, ISTEP, F-75005, Paris, France

CNRS, UMR 7193, ISTEP, F-75005, Paris, France

Keywords: Earth and planetary interiors, mineralogy, mantle, core, high-pressure, X-ray diffraction.

\begin{abstract}
This paper aims at reviewing the current advancements of high pressure experimental geosciences. The angle chosen is that of in situ measurements at the high pressure (P) and high temperature (T) conditions relevant of the deep Earth and planets, measurements that are often carried out at large facilities (X-ray synchrotrons and neutron sources). Rather than giving an exhaustive catalogue, four main active areas of research are chosen: the latest advancements on deep Earth mineralogy, how to probe the properties of melts, how to probe Earth dynamics, and chemical reactivity induced by increased P-T conditions. For each area, techniques are briefly presented and selected examples illustrate their potentials, and what that tell us about the structure and dynamics of the planet.
\end{abstract}

Email address: chrystele.sanloup@ upmc.fr (CHRYSTÈLE SANLOUP) 


\title{
Expérimentation à haute pression en géosciences: état de l'art et perspectives
}

\author{
Chrystèle SANLOUP \\ UPMC Univ Paris 06, UMR 7193, ISTEP, F-75005, Paris, France \\ CNRS, UMR 7193, ISTEP, F-75005, Paris, France
}

Mots-clés: Terre interne et planètes, minéralogie, manteau, noyau, haute-pression, diffraction X.

\begin{abstract}
Cet article présente une revue des connaissances et techniques expérimentales de haute pression en géosciences. L'angle choisi est celui des mesures in situ à haute pression $(\mathrm{P})$ et haute température (T), conditions qui sont celles de la Terre profonde et des planètes; de ce fait, la plupart des résultats présentés sont issus d'expériences utilisant des grands instruments (sources de rayonnement X synchrotron et sources de neutrons). Plutôt que de dresser un catalogue exhaustif, quatre domaines de recherche principaux sont choisis: la minéralogie de la Terre profonde, les propriétés des liquides géophysiques, l'imagerie des matériaux sous pression, et la réactivité chimique induite par des conditions P-T élevées. Pour chaque domaine, les techniques sont brièvement présentées, des exemples donnés pour les illustrer ainsi que les connaissances que l'on en tire sur la structure et la dynamique de la Terre.
\end{abstract}

Email address: chrystele.sanloup@upmc.fr(CHRYSTÈLE SANLOUP) 


\section{Introduction}

Earth sciences belong traditionally to observational sciences, generating numerous precise data and raising by empirical observation interesting physical and chemical relationships, which would have been unnoticed otherwise. For instance, pioneers such as F. Birch realized in the early $1950^{\text {ies }}$ that seismic data (showing density and velocity profiles as a function of depth) could be explained by variations of the physical properties of terrestrial materials under the increasing P-T conditions inside the planet (from $10^{5} \mathrm{~Pa}$ to $3.6510^{11} \mathrm{~Pa}$ for pressure, i.e. 6 orders of magnitude variation). At such conditions, the chemical constituents exhibit diverse and rich, unexpected physical and chemical phenomena.

The advances cited below result from the combination of high P-T techniques, with, essentially, recent developments at large light sources. Photon fluxes to-date at third generation X-ray synchrotron facilities are over 10 orders of magnitude higher than the flux delivered by an X-ray cathodic tube (Fig.1). High P experiments at neutron facilities have for long been limited to 10 $\mathrm{GPa}$ at the high $\mathrm{T}$ required for geosciences applications, as diffraction signals could not be detected for sample volumes less than $10-100 \mathrm{~mm}^{3}$. But sample volumes down to $1 \mathrm{~mm}^{3}$ (and equivalent $\mathrm{P}$ up to 50-100 GPa) are now sufficient for newly built high flux spallation sources (Oak Ridge National Lab., USA; or the J-Sparc project in Japan). That is opening great perspectives for the study of hydrated minerals and volatiles at depth, as neutrons can efficiently probe these light elements (Wenk, 2006).

In terms of high P-T techniques, static tools such as diamond-anvil cells (DAC) and multianvil presses (MAP) have basically reached their limits in terms of maximum achievable P-T conditions (see Fig.1), with MAP covering the upper mantle P-T range if using conventional WC anvils (and up to $60 \mathrm{GPa}$ at high $\mathrm{T}$ if using sintered diamond anvils), laser heated DAC covering all terrestrial P-T conditions. The developments, latest and to come, are achieved by adapting the HP-HT techniques to many different types of probes. 


\section{Crystalline phases in the deep Earth}

\subsection{Identifying major phases}

There has been tremendous progress in the exploration of crystalline planetary materials at extreme P-T conditions. For mantle silicates, this exploration has applied to the phase diagrams, crystal structures and equations of state and now covers the entire mantle P-T range (see ref. Ringwood (1991); Duffy (2008); Stixrude and Lithgow-Bertelloni (2011) for reviews). It is well illustrated by the discovery of the magnesian silicate post-perovskite phase (Murakami et al., 2004), unveiling the material present in the deepest few hundred kilometers of the mantle. In contrast with our good knowledge of mantle mineralogy, the structure of Fe in the inner core remains an open question (Fig. 2). Among the latest results, theoretical work and experiments carried on an $\mathrm{Fe}_{0.9} \mathrm{Ni}_{0.1}$ alloy favour a body-centered cubic phase (Dubrovinsky et al., 2007) while experiments on pure Fe showed no other stable phase than $\epsilon$-Fe up to $377 \mathrm{GPa}-5700 \mathrm{~K}$ (Tateno et al., 2010), i.e. a value exceeding by $13 \mathrm{GPa}$ the pressure at the center of the Earth, a record for static high P-T conditions; this result thus remains to be reproduced.

\subsection{Measuring the speed of sound: Birch's legacy}

The mineralogical composition of the deep mantle is tested essentially against seismological profiles. Such is the method initiated by F. Birch (Birch, 1964) by comparing density-velocity relationships (the so called 'Birch's law') between simple compounds and seismological data. Ideally, one should compare experimental data directly with seismological velocity profiles. F. Birch was also the first to point out that the core is mostly made of Fe plus some light elements (Birch, 1952). $10 \pm 5 \mathrm{wt} \%$ of light elements (Poirier, 1994) are needed to reduce the mismatch between seismological and experimental acoustic velocity profiles for pure liquid Fe (Brown and McQueen, 1986) (Fig.3 left). Measuring acoustic velocities on minerals at high P-T conditions, is mostly restricted to upper mantle conditions by propagating ultrasonic waves through a sample squeezed in a multi-anvil press (Li et al., 1996; Sinogeikin and Bass, 1999). To get to lower mantle 
and core conditions, inelastic scattering techniques are DAC-compatible. Brillouin scattering for instance can be used but is limited to transparent materials such as quartz (Gregoryanz et al., 2003) unlike X-ray inelastic scattering. This technique has not yet been applied for silicates at lower mantle conditions, but significant works have been published on $\mathrm{Fe}$ and $\mathrm{Fe}$-alloys, initially at room T (Fiquet et al., 2001) and up to $1700 \mathrm{~K}$ (Lin et al., 2005b). The good matching between room $\mathrm{T}$ results and shock-wave data attests that the linear relationship between density and the compressional wave velocity, $\mathrm{V}_{P}$, is verified for pure Fe (Fig.3), independently of $\mathrm{T}$ as, during shock-wave experiments, $\mathrm{T}$ reached several thousands $\mathrm{K}$ depending on the targeted $\mathrm{P}$ (Brown and McQueen, 1986). The slight offset between experimentally measured $\mathrm{V}_{P}$ on solid $\mathrm{Fe}$ and seismically observed values (Fig.3) suggests the presence of light elements not only in the outer core but also in the solid inner core (a few wt \%), a suggestion confirmed by the comparison between Fe density measurements up to 200 GPa and the PREM density profile (Dewaele et al., 2006). The inelastic scattering technique is nonetheless limited to room or modest $\mathrm{T}$, and gives much higher error bars on shear wave velocity, $\mathrm{V}_{S}$, measurements with large discrepancies both between different groups and with the PREM model for the inner core (Antonangeli et al., 2004), discrepancy that could be due to a high $\mathrm{T}$ effect on $\mathrm{V}_{S}$ (Lin et al., 2005b). The limitations come from the long data acquisition time (order of 1 hour) that for now prevents the use of stable laserheating at very high $\mathrm{T}$ as needed to reproduce lower mantle and core conditions. The achievement of this technique will ideally constrain: 1) the lower mantle geotherm and mineralogical models, two intrinsically linked issues, and 2) the light elements enigma of the outer core. The nature and precise amount of light elements is indeed still not resolved, with $\mathrm{Si}, \mathrm{O}, \mathrm{S}, \mathrm{C}$, and $\mathrm{H}$ as the most likely ones (Poirier, 1994).

\subsection{Measuring reaction kinetics}

Measuring reaction kinetics is essential to understand processes controlling mineralogical transformations (nucleation and growth process), and as such, essential to unravel the history of rocks recovered from high $\mathrm{P}-\mathrm{T}$ conditions. This has been done in the past mainly by performing se- 
ries of high P-T experiments on different time lengths, and measuring crystal growth on quenched samples. Besides the artifacts that may occur upon quenching an experiment, this method can not be applied if minerals are not stable back to ambient conditions. In situ measurements using timeresolved X-ray diffraction combined with MAP on olivine have been first performed on analogues of mantle olivine that undergo phase transitions at lower $\mathrm{P}\left(\mathrm{Mg}_{2} \mathrm{GeO}_{4}\right.$ by Lauterjung and Will (1986) and $\mathrm{Ni}_{2} \mathrm{SiO}_{4}$ by Rubie et al. (1990)), and later on mantle compositions (Mosenfelder et al., 2001; Kubo et al., 2004). Crystal growth is estimated from the phase proportions, themselves extracted from X-ray diffraction spectra, provided that the sample has a good powder quality pattern. These studies showed that even on a geological timescale, the olivine/spinel reaction needs to be overstepped in pressure at relatively high T (e.g., $1300 \mathrm{~K})$ for the transformation to start, consistent with olivine surviving metastably in slabs to very significant depths below the equilibrium phase boundary. More recently, Perrillat et al. (2005) have studied the mechanisms and rate of antigorite dehydration at the P-T conditions prevailing in slabs down to $150 \mathrm{~km}$. Antigorite belongs to the serpentine group, and is formed by hydrothermal alteration of the oceanic lithosphere. The dehydration reaction appeared to be kinetically controlled by surface growth processes, and yields fluid discharge rates high enough to increase the fluid pressure up to the failure condition, hence promoting earthquakes in the slab mantle.

\section{Probing the properties of molten materials at depth}

Planets were born molten (Harper, 1996), this early state being referred to as the magma ocean. During this period, segregation of the siderophile elements (mostly Fe) towards the center of the planet required them to pass through a molten silicate matrix. Similarly, the transport of volatiles to or from the deep interior, which created the primary atmosphere, occurred through a silicate liquid. Planetary differentiation, i.e. the way planets acquired their present internal structure shortly after accretion, is therefore controlled in the first instance by the properties of silicate and Fe melts at the P-T conditions of the interiors of planets. In the present day Earth, molten materials at 
depth include essentially the liquid outer core, the only fully molten layer of the planet. Besides, in addition to the relatively high-levels rising erupting magmas, there is evidence from various geophysical observations (seismology, electrical resistivity measurements) for the occurrence of liquids which are gravitationally stable at different depths of the mantle. Hydrated magmas could thus be regionally stable at the base of the lithosphere (Mierdel et al., 2007) and in the transition zone (Song et al., 2004), between 440 and $660 \mathrm{~km}$ depth. Last but not least, the presence of magmas at depth could explain the observed ultra-low seismic velocity zones at the bottom of the mantle (Williams and Garnero, 1996; Labrosse et al., 2007).

Despite their geophysical importance, data on molten geomaterials at depth are very scarce. In general, high P-T experiments on melts are technically challenging as those are difficult to confine, especially since it often implies to work at very high $\mathrm{T}$ at the limits of the experimental capacities. Very high $\mathrm{T}$ also imply very high chemical diffusivities and potential chemical reactions between sample and its container. On top of these difficulties, melts do not have long-range order by definition although they do have short- and medium-order range. That means that their scattering power is weak, both for X-rays/neutrons, or for Raman spectroscopy. Although they are progress under way, it is not possible yet to collect Raman spectra above $1000 \mathrm{~K}$, as the sample thermal emissivity would cover its own Raman signal. Probing melts properties in situ has thus been impossible for long, and just over the last 10 years.

\subsection{Melting relationships}

Unambiguous criteria for melting imply detection of a signal from the melt instead of just loosing the signal from the crystalline phase, as shown on fig. 4 with the appearance of a diffuse X-ray scattering signal from molten Fe. That can also be done by visual observations of crystal melting through transparent windows such as diamonds (Datchi et al., 2000), but this technique is limited to relatively low $\mathrm{P}$ as the image gets blurred. It is now possible to detect the signal from a melt compressed in a DAC either by X-ray diffraction or Raman spectroscopy, and even for light materials as illustrated by the case of water (Lin et al., 2005a; Goncharov et al., 2009) 
and hydrogen (Gregoryanz et al., 2003). This enables to track the melting curve and melting relationships of planetary materials (Fig.5).

For water, following the discovery of the superionic phase ice $\mathrm{X}$ stable above $60 \mathrm{GPa}$ at room $\mathrm{T}$, efforts have been devoted to see if the melting curve changes at these pressures (Lin et al., 2005a; Goncharov et al., 2009). In these externally heated DAC experiments, melting was detected by an abrupt change of the $\mathrm{H}_{2} \mathrm{O}$ intramolecular Raman modes. As the melting curve of water becomes indeed very steep (Fig.5, middle panel), it is expected to cross the temperature profile inside the ice-rich giant planets, Uranus and Neptune. Hence, a molten outer shell is expected in these planets. This configuration is consistent with the non-dipolar magnetic field structure of Uranus and Neptune, a structure that can be explained if magnetic field generation occurs in a thin shell surrounding an electrically conductive but non-convective layer (Stanley and Bloxham, 2004). For mantle materials, the melting relationships have been measured at all mantle conditions, including liquidus and solidus curves (Fiquet et al., 2010). Crystalline phases at the solidus change at 40 $\mathrm{GPa}$, from magnesiowustite to magnesian perovskite, without any further change down to the core-mantle boundary conditions apart from the perovskite to post-peroskite transition. More importantly, the measured solidus intersects estimated geotherm at $135 \mathrm{GPa}$ and $4180 \mathrm{~K}$. The presence of partial melt would thus provide an explanation for the observed seismic ultra-low velocity zones (ULVZ) in the D" layer at the bottom of the mantle. For core materials, Fe-S alloys have received the largest attention so far as the eutectic point has the lowest melting $\mathrm{T}$ amongst Fe-alloys, hence it is technically the easiest system to work with. A major effect of pressure is to shift the eutectic composition towards the Fe pole (Campbell et al., 2007; Stewart et al., 2007; Morard et al., 2008a), resulting in the sulfide phase being present at the solidus for potential core compositions containing $10 \pm 5 \mathrm{wt} \%$ light elements (Fig.6). If the melt released at the inner core boundary is richer in Fe than the crystallizing phase, that would obstruct chemical convection in the core and that brings a strong argument against sulphur being a major light element. 


\subsection{Density of melts}

To measure the density of melts at high P, X-ray radiographic techniques have been developed over the last 15 years (Katayama, 1996; Sanloup et al., 2000b), and rely on the density and hence absorption contrast between the sample and its high $\mathrm{P}$ environment (Fig.7 right). These techniques are compatible with large sample volumes only, and are therefore limited to the upper mantle P-T conditions. Density can also be extracted from the X-ray signal diffracted by the melt (Kaplow et al., 1965), a method compatible with DAC experiments (Eggert et al., 2002) .

I will now illustrate this section with the case of molten silicates. In the present-day Earth, many igneous/volcanic processes are influenced by the properties of molten silicate at depth (e.g. buoyancy forces, viscosity), considering that magmas are produced between 20 and $80 \mathrm{~km}$ (0.5 to 2.5 $\mathrm{GPa}$ ) at medio-oceanic ridges (Shen and Forsyth, 1995), and down to $150 \mathrm{~km}$ (5 GPa) in subduction zones. Nearly every stage in the genesis of magma depends on the density contrast between silicate liquids and crystals (Stolper et al., 1981): the rate of liquid segregation, its control on the equilibrium vs fractional fusion and on the degree of partial melting before extraction, the ascent rate of magmas. Few shock-wave studies are available (Ridgen et al., 1984; Akins et al., 2004). Their principal result is that there is a density cross-over between melt and solid silicates, which implies that silicate melts can be segregated at depth. Similar conclusions have been reached from ex situ experiments using the sink-float method (Agee, 1998). The sink-float method consists in inserting a density marker in the sample, and checking on the recovered sample quenched from high P-T conditions whether the marker has been floating or sinking in the sample; this method allows only few (1-3) data points to be collected along the equation of state. In the particular case of lunar basalts, their petrology is quite diverse, and some of them are particularly intriguing due to their high Ti content, making them very dense in addition to a high Fe content. Lunar interiors have regain interests lately due to a large number of recent missions to the Moon. Both the sink-float method (Circone and Agee, 1996) and X-ray absorption method (Sakamaki et al., 2010) have been applied to measure the density of high Ti lunar basalts (Fig.7), basalts generated at $\mathrm{P}$ 
around $1.5 \mathrm{GPa}$. There is over $5 \%$ spread amongst existing density data, both experimental and theoretical (Guillot and Sator, 2007). Although this spread prevents to reach a firm conclusion, it is possible that these high-Ti basalts could have sunk in the mantle, thus providing an explanation for the partially molten layer evidenced at the base of the lunar mantle by a recent re-interpretation of Apollo seismographs (Weber et al., 2011).

\subsection{Immiscible liquids}

Immiscibility affects many geologically relevant liquids: aqueous fluids/magmas, carbonatititic magmas/silicate magmas, magmas/molten Fe-alloy and even within molten Fe-alloys (Fig.10). Applying high pressure usually induces closure of the miscibility gap. Deciphering gap closure from quenched textures is often ambiguous as exsolution might occur upon T-quenching of the experiment (Kato and Ringwood, 1989). Gap closure has thus been evidenced by in situ visual observations through diamond anvil windows for fluids and magmas (Shen and Keppler, 1997), and by X-ray radiographic observations through multi-anvil press assemblies for fluids/magmas (Mibe et al., 2004) and for Fe-S/Fe-Si liquid alloys (Morard et al., 2008b). To get further insights into how $\mathrm{P}$ induces gap closure, structural information is required. In the case of Fe-S-Si melts, Fe-S and Fe-Si bonding is different in melts at ambient P: covalent for Fe-S and metallic for Fe-Si. Under increasing $\mathrm{P}$, structural evolution of the $\mathrm{Fe}-\mathrm{S}$ bond towards metallic bond was evidenced in the vicinity of gap closure (Morard et al., 2007), thus providing a rationale for it. Not all immiscible Fe-alloys have been studied yet under pressure, but Fe-S-C gap closes at 5 GPa (Corgne et al., 2008), and $\mathrm{Fe}-\mathrm{FeO}$ could close above $70 \mathrm{GPa}, \mathrm{P}$ at which the insulator to metallic transition has been reported for $\mathrm{FeO}$ (Knittle and Jeanloz, 1986). It is therefore unlikely that immiscibility plays a role in the Earth's core. However, for smaller planets with core P-range falling within immiscibility domains, core could have a complex shell structure (Fig.11) as proposed for planetesimals (Corgne et al., 2008) and present-day Mercury (Malavergne et al., 2010). 


\subsection{Melt percholation by X-ray tomography}

Imaging samples in situ at high P-T conditions is currently done using X-ray radiography techniques. These techniques are suitable to study samples compressed in large volume presses, using either monochromatic or white X-ray beam. X-ray radiographs can be collected simultaneously with X-ray diffraction data. X-ray radiography is the easiest technique to determine the sample position before collecting a diffraction pattern; in the case illustrated on Fig. 8 (Fei et al., 2004), the lherzolite powder sample was enclosed in a Re capsule and topped with two layers of pressure standards (MgO, Pd, Pt) with the purpose of measuring equation of states. Radiographs also allow to measure the sample shape and size with a current resolution of the order of $1 \mu \mathrm{m}$. Applications of these combined techniques are numerous, as illustrated by a few examples below. Another as yet unresolved issue is the scenario of core formation, and whether the percolation of molten Fealloys occurred through a solid or molten silicate matrix (Stevenson, 2008). Percolation has been studied mainly by analysis of the texture of quenched samples (Minarik et al., 1996; Shannon and Agee, 1998), which showed non-connected Fe-alloys islands among the silicate matrix. These results are in contradiction with in situ electrical resistivity measurements (Yoshino et al., 2003) as those did imply a connectivity of the molten Fe-S alloy under pressure for similar Fe-S/olivine volume ratio. To solve this apparent contradiction and to get quantitative data on percolation mechanisms (e.g. dihedral angles), the issue is to get in situ 3-D imaging data. An example of 3-D reconstruction from a collection of 2-D radiographs is shown on Fig. 9. At ambient conditions, X-ray tomography is ideal as a non invasive or destructive method to study materials such as precious fossil records (Kruta et al., 2011), as opposed to SEM analyses on slabs for instance. Among applications of X-ray tomography under pressure, and besides the study of fluid percolation, this technique would be suited for volume measurements of non-crystalline samples (amorphous or liquids), and consequently, for the measurement of their equation of states (Wang et al., 2005; Lesher et al., 2009).

The present spatial resolution being close to $1 \mu \mathrm{m}$ prevents for now the use of this technique 
with diamond-anvil cell samples of size less than $10 \mu \mathrm{m}$; the development of nanoscale X-ray tomography beamlines at synchrotron facilities should push this limit and allow precise sample imaging up to the megabar in the decade to come.

\section{Probing Earth dynamics}

\subsection{Rheology at depth}

Scientists aim at extrapolating laboratory deformation data on earth materials at large strains and low strain rates, to understand geodynamic processes over time scales of millions of years, under extreme P-T conditions. The D-DIA apparatus is a type of multi-anvil press that allows to impose differential stress, and thus deform a sample under pressure. There has for long been a compromise between detailed analysis at room P-T of deformation mechanisms on samples deformed at extreme conditions (Cordier et al., 2004) and in situ but qualitative-only information (Chen et al., 2002).

In situ techniques have been recently improved and successfully applied on an antigorite-serpentinite sample compressed up to $4 \mathrm{GPa}$ and $500^{\circ} \mathrm{C}$ (Hilairet et al., 2007). Its viscosity could be measured quantitatively thus confirming antigorite as an ideal candidate for strain localization within subduction zones. Stress is measured from the X-ray diffraction pattern as differential stress results in peak broadening and variations of the crystal inter-planar distances $\left(d_{h k l}\right)$, while strain and strain rate are deduced from the sample length on radiographs. This technique is currently limited to the $20 \mathrm{GPa}$ range (Kawazoe et al., 2010). It is nonetheless possible to gain insights on the crystalline deformation mechanisms at more extreme conditions. The technique consists in 1) collecting the X-ray diffraction data in radial geometry, i.e. perpendicularly to the symmetry axis of the diamond-anvil cell defined by the alignment of the anvils and along which maximum stresses are consequently generated, and 2) avoiding the presence of a pressure-transmitting medium, which essential task is to prevent anhydrostaticity to develop. Deformation mechanisms and the resulting texture in polycrystalline samples can be determined from the measured variations in diffraction 
peaks position and intensity as a function of the azimuthal angle on a 2-D diffraction image. In the convecting mantle, anisotropy is strongest in boundary layers, i.e. in the lithosphere and the D" layer at the base of the mantle (Panning and Romanowicz, 2004). Hence the need to understand deformation mechanisms in these regions. The anisotropic deformation of polycrystalline $\mathrm{MgSiO}_{3}$ post-perovskite has been investigated from $145 \mathrm{GPa}$ to $185 \mathrm{GPa}$ and deformation-induced slip planes could be identified (Merkel et al., 2007; Miyagi et al., 2010), providing an understanding of D" anisotropy. However, the technique is currently limited to room T, as high T promote grain growth and, consequently, the powder-quality of the X-ray diffraction pattern is lost, preventing the proper analysis of peaks intensity.

The rheology of molten geomaterials is easier to measure under pressure, apart from the high $\mathrm{T}$ involved that imply experimental difficulties (cf section 3 ). But these high $\mathrm{T}$ also imply much shorter deformation timescales, hence the techniques are more straightforward. The sink-float method records the falling of a sphere in the liquid by X-ray radiography and deduces the viscosity from the Stokes' equation. The viscosity of molten Fe at core conditions is a key parameter of core convection. Geophysical estimates of the viscosity vary over several order of magnitudes (Secco, 1995), from $10^{-2}$ to $10^{10} \mathrm{~Pa} \cdot \mathrm{s}$ depending on the method (geodesy, seismic wave attenuation, geomagnetism). On the lower end of this range, core flow would be turbulent and dominated by Coriolis forces, while it would be more regular and dominated by viscous forces for the highest values. Experimental measurements have confirmed the lower values of $1-2 \times 10^{-2} \mathrm{~Pa} \cdot \mathrm{s}$ (Terasaki et al., 2002, 2006), and light elements such as S and C seem to have little effect.

\subsection{Transport properties: electrical and thermal conductivity}

The discovery of the deepest silicate mineral of the Earth's mantle, i.e. the post-perovskite phase (Murakami et al., 2004), has unveiled many geodynamical phenomena. Besides being highly anisotropic just as the D" layer is seismologically, the post-perovskite phase has indeed many interesting properties. Among those, its increased electrical conductivity (Ohta et al., 2008) 
compared to the perovskite phase provides a mechanism for the observed correlation between variations of the Earth's rotation rate and of the Earth's magnetic field (Courtillot et al., 1982) by an electro-magnetic coupling between mantle and core flow.

Mantle convection and plate tectonics are driven by the heat flow from Earth's core to the surface. The heat flow in turn is controlled by the thermal conductivity of minerals. The higher the thermal conductivity is, the less efficient the convection is to transfer heat $v s$. conduction. On the core side, the thermal conductivity of Fe controls the amount of heat escaping from the core. However, few measurements have been made for thermal conductivity over $10 \mathrm{GPa}$ (Ross et al., 2005). Thermal conductivity measurements at extreme conditions are very challenging experiments, but first breakthroughs have been achieved on perovskite (Goncharov et al., 2008; Keppler et al., 2008). These results show that although usually assumed to be negligible, radiation dominates heat conduction in the deep mantle.

\section{Chemical reactivity/geochemical affinity}

The three categories of atmophile, lithophile, and siderophile elements, have been defined and used by Victor M. Goldschmidt to establish a geochemical classification of the elements, and they all refer to the affinity of the elements for liquid phases at ambient pressure. Hence the chemical affinity of the elements is a key property to derive the composition of the reservoirs, 'atmophile' in the atmosphere, 'lithophile' in the rocky mantle, and 'siderophile' elements in the core. Goldschmidt classification of the elements is also used to trace planetary differentiation in terms of processes and timing, by using a radioactive mother/daughter elements pair with different chemical affinities. The chemical properties of terrestrial materials remain largely unexplored across the broad range of Earths extreme conditions, and are very often assumed constant and equal to those known at ambient conditions. Two examples that follow will illustrate how that is not the case.

Oxygen and silicon, typical lithophile elements (i.e. major constituents of rocks at ambient P), 
have been shown to partition into molten Fe above 70 GPa (Jeanloz and Knittle, 1991) and even more in the P-stability field of the post-perovskite phase (Sakai et al., 2006). It follows that there are likely to be the most abundant light elements in the core, sulphur being a siderophile element at all investigated P-T conditions but too volatile to be present in more than a few \% (Dreibus and Palme, 1996).

In the case of atmosphere formation, the ${ }^{129} \mathrm{I} \rightarrow{ }^{129} \mathrm{Xe}$ radioactivity is used, with a half-life of $17 \mathrm{My}$. In that case iodine is a lithophile element and xenon, as a gas, an atmophile element. ${ }^{129} \mathrm{Xe}$ excesses compared to chondritic meteorites measured in the cortex of pillow-lavas show that the mantle was largely degassed within $100 \mathrm{My}$. Argon and helium isotopes are also used to assess atmosphere formation, but on much larger timescales. In these datation processes, the potential pressure dependence of the chemical affinity is not considered. However, heavy rare gases do change behaviour under high P-T conditions. Upon melting at room pressure, noble gases strongly partition into the melt which is an incompatible behaviour (i.e. incompatible with the cristalline network). Two independent groups have shown that such is not the case under pressure, as they observed a solubility drop of Ar at $5 \mathrm{GPa}$ in olivine and silica melts (Chamorro-Perez et al., 1996, 1998; Bouhifd and Jephcoat, 2006), and higher in more chemically complex melts (Bouhifd and Jephcoat, 2006). Even more problematic is the chemistry of xenon at high P-T conditions. Although an archetypical inert element at ambient conditions, xenon can be covalently bonded to oxygen in silica at the conditions of the Earth's continental crust, through a Xe-Si substitution in the tetrahedra (Sanloup et al., 2005). From atmophile at ambient conditions, Xe therefore becomes lithophile at depth. Those results question the use of noble gases isotopes as tracers of Earth's dynamics.

More generally, the chemical affinity of elements should not be assumed constant and equal to that known at ambient pressure, neither should the partitioning of volatile elements be studied on quenched experiments. Ideally, one should measure the partition coefficient of an element, i.e. its concentration ratio between two co-existing phases, with in situ probes. Partitioning coefficients 
are traditionally measured from quenched experiments, with the associated draw-backs such as exsolutions or precipitations upon quenching. Pioneer studies have thus been carried on the partition of trace elements in fluids using X-ray fluorescence combined with diamond-anvil cell techniques (Sanchez-Valle et al., 2003; Bureau et al., 2007). The presence of diamonds limits however this technique to the study of elements heavier than Fe, so that the fluorescence signal is not absorbed by the anvils. These studies are also for now limited to moderate pressures ( $<5 \mathrm{GPa}$ ). For instance, bromine (Br) concentration in melts and aqueous fluids could be measured with this method at P-T conditions relevant of magma generation and ascent in subduction zones (Bureau et al., 2009). The results show that $\mathrm{Br}$ has a large affinity for magmas at depth, and that suggests that $\mathrm{Br}$ is partly recycled in the mantle rather than being totally extracted from the subducted plates with aqueous fluids upon dehydration and further degassed.

\section{Conclusions}

Earth's sciences have profoundly benefited from the confrontation of experimental petrology and observations, both petrological and seismological. This confrontation has unveiled the deep structure and composition of the planet, and a clear understanding of its formation and differentiation is underway. A rich area has been the discovery of new pressure-induced chemistry in volatiles under conditions ranging from those of deep marine sediments to the deepest planetary interiors. A common theme of this recent work is the need for in situ high P-T study because many of these transitions and new mineral phases cannot be observed in quenched samples and in the near-surface environment of planets.

Nonetheless, one should keep in mind the limitations of high P experimentation in Earth's sciences. The first and main one is certainly the extrapolation of scales in space (from the $\mu \mathrm{m}$ to $\mathrm{mm}$ lab scale to the $1000 \mathrm{~km}$ Earth's scale) and time (from the picosecond to a maximum of a few days for the lab scale depending on the probed phenomena, to the $10^{9} \mathrm{y}$ geological scale). The second limitation comes from the experimental chemical systems, which are necessarily less 
complex than real terrestrial rocks for the sake of proper data processing and interpretation of the results.

The next challenges are thus to push forward these current limitations, to adapt techniques currently available only at room $\mathrm{P}$ to measure crucial properties such as thermal conductivity (cf mantle convection modeling), and to ever increase the experimental P-T range. Dynamic techniques are witnessing important developments. Aside from refinements of the classic shock-wave gun by using pre-compressed samples for instance, laser sources now routinely generate shocks over $100 \mathrm{GPa}$, and the $\mathrm{TPa}\left(10^{12} \mathrm{~Pa}\right)$ is targeted by the high power laser facilities. Exploring the interiors of giant planets (4000 GPa-20 $000 \mathrm{~K}$ at the center of Jupiter) and extra-solar planets is getting within reach. Detected exoplanets are necessarily super-giants if detected. Could their interiors contain new ultrahigh P silicate phases (post-post-perovskite) or metallic ices? What are the melting curves of these exoplanetary materials? All issues that for now can be explored only by numerical modeling. Today, calculating is indeed a third tool in our box, in addition to HP-HT experiments and observations. Although numerical modeling was out of the scope of this paper, the discovery of the post perovskite phase in the lower most mantle is a very nice demonstration of this change since both aspects (extreme HP-HT experiments and atomic scale calculations) were involved.

\section{Acknowledgements}

I thank A. Dewaele and C. Crépisson for their comments on a preliminary version of this article.

\section{References}

Agee, C. B., 1998. Crystal-liquid density inversions in terrestrial and lunar magmas. Phys. Earth Planet. Int. 107, 63-74.

Akins, J. A., Luo, S.-N., Asimow, P. D., Ahrens, T. J., 2004. Shock-induced melting of $\mathrm{MgSiO}_{3}$ perovskite and implications for melts in Earth’s lowermost mantle. Geophys. Res. Lett. 31, L14612. 
Antonangeli, D., Ocelli, F., Requardt, H., Badro, J., Fiquet, G., Krisch, M., 2004. Elastic anisoptropy in textured hcp-iron to $112 \mathrm{GPa}$ from sound wave propagation measurements. Earth Planet. Sci. Lett. 225, 243-251.

Birch, F., 1952. Elasticity and constitution of the Earth's interior. J. Geophys. Res. 57, 227-286.

Birch, F., 1964. Density and composition of mantle and core. J. Geophys. Res. 69, 4377-4388.

Boehler, R., 1993. Temperature in the Earth's core from melting point measurements of iron at high static pressures. Nature 363, 534-536.

Bouhifd, M. A., Jephcoat, A., 2006. Aluminium control of argon solubility in silicate melts under pressure. Nature 439, 961-964.

Brown, J. M., McQueen, R. J., 1986. Phase transitions, Grneisen parameter, and elasticity for shocked iron between $77 \mathrm{GPa}$ and $400 \mathrm{GPa}$. J. Geophys. Res. 91, 7485-7494.

Bureau, H., Foy, E., Raepsaet, C., Somogyi, A., , Munsch, P., Simon, G., Kubsky, S., 2009. Bromine cycle in subduction zones through in situ Br monitoring in diamond anvil cells. Geochim. Cosmochim. Acta 74, 3839-3850.

Bureau, H., Menez, B., Malavergne, V., Somogyi, A., Simionovici, A., Massare, D., Khodja, H., Daudin, L., Gallien, J.-P., Shaw, C., Bonnin-Mosbah, M., 2007. In situ mapping of high-pressure fluids using hydrothermal diamond anvil cells. High Pressure Research 27, 235-247.

Campbell, A. J., Seagle, C. T., Heinz, D. L., Shen, G., Prakapenka, V. B., 2007. Partial melting in the iron-sulfur system at high pressure: A synchrotron X-ray diffraction study. Phys. Earth Planet. Inter. 162, 119-128.

Chamorro-Perez, E. M., Gillet, P., Jambon, A., 1996. Argon solubility in silicate melts at very high pressures. experimental set-up and preliminary results for silica and anorthite melts. Earth Planet. Sci. Lett. 145, 97-107.

Chamorro-Perez, E. M., Gillet, P., Jambon, A., MacMillan, P. F., Badro, J., 1998. Low argon solubility in silicate melts at high pressure. Nature 393, 352-355.

Chen, J. H., Weidner, D. J., Vaughan, M. T., 2002. The strength of $\mathrm{Mg}_{0.9} \mathrm{Fe}_{0.1} \mathrm{SiO}_{3}$ perovskite at high pressure and temperature. Nature 419, 824-826.

Chudinovskikh, L., Boehler, R., 2007. Eutectic melting in the FeS system to 44 GPa. Earth Planet. Sci. Lett. 257, 97-103.

Circone, S., Agee, C. B., 1996. Compressibility of molten high-Ti mare glass: Evidence for crystal-liquid density inversions in the lunar mantle. Geochim. Cosmochim. Acta 60, 2709-2720.

Cordier, P., Ungár, T., Zsoldos, L., Tichy, G., 2004. Dislocation creep in $\mathrm{MgSiO}_{3}$ perovskite at conditions of the Earth's uppermost lower mantle. Nature 428, 837-840.

Corgne, A., Wood, B. J., Fei, Y., 2008. C- and S-rich molten alloy immiscibility and core formation of planetesimals. Geochim. Cosmochim. Acta 72, 2409-2416.

Courtillot, V., Mouel, J. L. L., Ducruix, J., Cazenave, A., 1982. Geomagnetic secular variations as a precursor of climatic change. Nature 297, 386-387.

Datchi, F., Loubeyre, P., LeToullec, R., 2000. Extended and accurate determination of the melting curves of argon, 
helium, ice $\left(\mathrm{H}_{2} \mathrm{O}\right)$, and hydrogen $\left(\mathrm{H}_{2}\right)$. Phys. Rev. B 61, 6535-6546.

Dewaele, A., Loubeyre, P., Occelli, F., Mezouar, M., Dorogokupets, P. I., Torrent, M., 2006. Quasihydrostatic equation of state of iron above 2 Mbar. Phys. Rev. Lett. 97, 215504.

Dewaele, A., Sanloup, C., 2005. L'intérieur de la Terre et des planètes. Belin, Paris.

Dreibus, G., Palme, H., 1996. Cosmochemical constraints on the sulfur content in the Earth's core. Geochim. Cosmochim. Acta 60, 1125-1130.

Dubrovinsky, L., Dubrovinskaia, N., Narygina, O., Kantor, I., Kuznetzov, A., Prakapenka, V. B., Vitos, L., Johansson, B., Mikhaylushkin, A. S., Simak, S. I., Abrikosov, I. A., 2007. Body-centered cubic iron-nickel alloy in Earth's core. Science 316, 1880-1883.

Duffy, T. S., 2008. Some recent advances in understanding the mineralogy of Earth's deep mantle. Philos. Trans. R. Soc. A-Math. Phys. Eng. Sci. 366 (1883), 4273-4293.

Dziewonski, A. M., Anderson, D. L., 1981. Preliminary reference Earth model. Phys. Earth Planet. Int. 25, $297-356$.

Eggert, J. H., Weck, G., Loubeyre, P., Mezouar, M., 2002. Quantitative structure factor and density measurements of high-pressure in diamond anvil cells by x-ray diffraction: Argon and water. Phys. Rev. B 65, 174105-1-17410512.

Fei, Y., Bertka, C. M., Finger, L. W., 1997. High-pressure iron-sulfur compound, $\mathrm{Fe}_{3} \mathrm{~S}_{2}$, and melting relations in the system Fe-FeS at high pressure. Science 275, 1621-1624.

Fei, Y., Li, J., Bertka, C. M., Prewitt, C. T., 2000. Structure type and bulk modulus of $\mathrm{Fe}_{3} \mathrm{~S}$, a new iron-sulfur compound. Amer. Min. 85, 1830-1833.

Fei, Y., van Orman, J., Li, J., van Westrenen, W., Sanloup, C., Minarik, W., Hirose, K., Komabayashi, T., Walter, M., Funakoshi, K., 2004. Experimentally determined postspinel transformation boundary in $\mathrm{Mg}_{2} \mathrm{SiO}_{4}$ using $\mathrm{MgO}$ as an internal pressure standard and its geophysical implications. J. Geophys. Res. 109, B02305.

Fiquet, G., Auzende, A. L., Siebert, J., Corgne, A., Bureau, H., Ozawa, H., Garbarino, G., 2010. Melting of peridotite to 140 Gigapascals. Science $329,1516-1518$.

Fiquet, G., Badro, J., Guyot, F., Requardt, H., Krisch, M., 2001. Sound velocity in iron to 110 Gigapascals. Science $291,468-471$.

Goncharov, A. F., Haugen, B. D., Struzhkin, V. V., Beck, P., Jacobsen, S. D., 2008. Radiative conductivity in the Earths lower mantle. Nature 456, 231-234.

Goncharov, A. F., Sanloup, C., Goldman, N., Crowhurst, J. C., Bastea, S., Howard, W. M., Fried, L. E., Guignot, N., Mezouar, M., Meng, Y., 2009. Dissociative melting of ice VII at high pressure. J. Chem. Phys. 130, 124514.

Gregoryanz, E., Goncharov, A. F., Matsuishi, K., k. Mao, H., Hemley, R. J., 2003. Raman spectroscopy of hot dense hydrogen. Phys. Rev. Lett. 90, 175701.

Guillot, B., Sator, N., 2007. A computer simulation study of natural silicate melts. Part II: High pressure properties. Geochim. Cosmochim. Acta 71, 4538-4556. 
Harper, C. L., 1996. Evidence for ${ }^{92 g} \mathrm{Nb}$ in the early solar system and evaluation of a new $p$-process cosmochronometer from ${ }^{92 g} \mathrm{Nb} /{ }^{92} \mathrm{Mo}$. ApJ 466, 437-456.

Hilairet, N., Reynard, B., Wang, Y., Daniel, I., Merkel, S., Nishiyama, N., Petitgirard, S., 2007. High-Pressure creep of serpentine, interseismic deformation, and initiation of subduction. Science 318, 1910-1913.

Jeanloz, R., Knittle, E., 1991. Earth's core-mantle boundary: results of experiments at high pressures and temperatures. Science $251,1438-1443$.

Kaplow, R., Strong, S. L., Averbach, B. L., 1965. Radial density functions for liquid mercury and lead. Phys. Rev. 138, A1336.

Katayama, Y., 1996. Density measurements of non-crystalline materials under high pressure and high temperature. High Pressure Res. 14, 383-391.

Kato, T., Ringwood, A. E., 1989. Melting relationships in the system Fe-FeO at high pressures: implications for the composition and formation of the Earth's core. Phys. Chem. Minerals 16, 524-538.

Kawazoe, T., Norimasa, N., Nishihara, Y., Irifune, T., 2010. Deformation experiment at P-T conditions of the mantle transition zone using D-DIA apparatus. Phys. Earth Planet. Int. 183, 190-195.

Keppler, H., Dubrovinsky, L. S., Narygina, O., Kantor, I., 2008. Optical absorption and radiative thermal conductivity of silicate perovskite to 125 Gigapascals. Science 322, 1529-1532.

Knittle, E., Jeanloz, R., 1986. High-pressure metallization of FeO and implications for the Earth's core. Geophys. Res. Lett. 13, 1541-1544.

Kruta, I., Landman, N., Rouget, I., Cecca, F., Tafforeau, P., 2011. The role of ammonites in the mesozoic marine food web revealed by jaw preservation. Science 331, 70-72.

Kubo, T., Ohtani, E., Funakoshi, K., 2004. Nucleation and growth kinetics of the alpha-beta transformation in $\mathrm{Mg}_{2} \mathrm{SiO}_{4}$ determined by in situ synchrotron powder X-ray diffraction. Am. Mineral. 89, 285-293.

Labrosse, S., Hernlund, J. W., Coltice, N., 2007. A crystallizing dense magma ocean at the base of the Earths mantle. Nature 450, 866-869.

Lauterjung, J., Will, G., 1986. The kinetics of the olivine-spinel transformation in $\mathrm{mg}_{2} \mathrm{geo}_{4}$ under high pressure and temperature. Physica B C 139, 343-346.

Lesher, C. E., Wang, Y., Gaudio, S., Clark, A., Nishiyama, N., Rivers, M., 2009. Volumetric properties of magnesium silicate glasses and supercooled liquid at high pressure by x-ray microtomography. Phys. Earth Planet. Int. 174, 292-301.

Li, B., Jackson, I., Gasparik, T., Liebermann, R., 1996. Elastic wave velocity measurement in multi-anvil apparatus to $10 \mathrm{GPa}$ using ultrasonic interferometry. Phys. Earth Planet. Int. 98 (1-2), 79-91.

Lin, J. F., Gregoryanz, E., Struzhkin, V. V., Somayazulu, M., Mao, H. K., Hemley, R. J., 2005a. Sound velocities of iron-nickel and iron-silicon alloys at high pressures. Geophys. Res. Lett. 32, L11306.

Lin, J. F., Sturhahn, V., Zhao, J., Shen, G., Mao, H. K., Hemley, R. J., 2005b. Sound velocities of hot dense iron: 
Birch's law revisited. Science 308, 1892-1894.

Malavergne, V., Tarrida, M., Combes, R., Bureau, H., Jones, J., Schwandt, C., 2007. New high-pressure and hightemperature metal/silicate partitioning of $\mathrm{U}$ and $\mathrm{Pb}$ : Implications for the cores of the Earth and Mars. Geochim. Cosmochim. Acta 71, 2635-2655.

Malavergne, V., Toplis, M. J., Berthet, S., Jones, J., 2010. Highly reducing conditions during core formation on Mercury: Implications for internal structure and the origin of a magnetic field. Icarus 206, 199-209.

Merkel, S., McNamara, A. K., Kubo, A., Speziale, S., Miyagi, L., Meng, Y., Duffy, T. S., Wenk, H.-R., 2007. Deformation of $(\mathrm{Mg}, \mathrm{Fe}) \mathrm{SiO}_{3}$ post-perovskite and D" anisotropy. Science 316, 1729-1732.

Mibe, K., Kanzaki, M., Kawamoto, T., Matsukage, K. N., Feu, Y., Ono, S., 2004. Determination of the second critical end point in silicate- $\mathrm{H}_{2} \mathrm{O}$ systems using high-pressure and high-temperature x-ray radiography. Geochim. Cosmochim. Acta 68, 5189-5195.

Mierdel, K., Keppler, H., Smyth, J. R., Langenhorst, F., 2007. Water solubility in aluminous orthopyroxene and the origin of earth's asthenosphere. Science 315, 364-2845.

Minarik, W. G., Ryerson, F. J., Watson, E. B., 1996. Textural entrapment of core-forming melts. Science 272, 530533.

Miyagi, L., Kanitpanyacharoen, W., Kaercher, P., Lee, K. K. M., Wenk, H.-R., 2010. Slip systems in MgSiO 3 postperovskite: Implications for D” anisotropy. Science 329, 1639-1641.

Morard, G., Andrault, D., Guignot, N., Sanloup, C., Mezouar, M., Petitgirard, S., Fiquet, G., 2008a. In situ determination of $\mathrm{Fe}_{-} \mathrm{Fe}_{3} \mathrm{~S}$ phase diagram and liquid structural properties up to $65 \mathrm{GPa}$. Earth Planet. Sci. Lett. 272, 620-626.

Morard, G., Sanloup, C., B.Guillot, Fiquet, G., Mezouar, M., Perrillat, J., Garbarino, G., Mibe, K., Komabayashi, T., Funakoshi, K., 2008b. In situ structural investigation of Fe-S-Si immiscible liquid system and evolution of Fe-S bond properties with pressure. J. Geophys. Res. 113, B10205.

Morard, G., Sanloup, C., Fiquet, G., Mezouar, M., Rey, N., Poloni, R., Beck, P., 2007. Structure of eutectic Fe-FeS melts to pressures up to $17 \mathrm{GPa}$ : Implications for planetary cores. Earth Planet. Sci. Lett. 263, 128-139.

Mosenfelder, J. L., Marton, F. C., Ross, C. R., Kerschhofer, L., Rubie, D. C., 2001. Experimental constraints on the depth of olivine metastability in subducting lithosphere. Phys. Earth and Planet. Int. 127, 165-180.

Murakami, M., Hirose, K., Kawamura, K., Sata, N., Ohishi, Y., 2004. Post-perovskite phase transition in $\mathrm{MgSiO}_{3}$. Science 304, 855-858.

Nguyen, J. H., Holmes, N. C., 2004. Melting of iron at the physical conditions of the Earth's core. Nature 427, 339-373.

Ohta, K., Onoda, S., Hirose, K., Sinmyo, R., Shimizu, K., Sata, N., Ohishi, Y., Yasuhara, A., 2008. The electrical conductivity of post-perovskite in Earth's D” layer. Science 320, 89-91.

Panning, M., Romanowicz, B., 2004. Inferences on flow at the base of Earth's mantle based on seismic anisotropy. 
Science $303,351-353$.

Perrillat, J.-P., Daniel, I., Koga, K., Reynard, B., Cardon, H., Crichton, W. A., 2005. Kinetics of antigorite dehydration: A real time x-ray diffraction study. Earth Planet. Sci. Lett. 236, 899913.

Poirier, J.-P., 1994. Light elements in the Earth's outer core: a critical review. Phys. Earth Planet. Int. 85, 319-337.

Ridgen, S. M., Ahrens, T. J., Stolper, E. M., 1984. Densities of liquid silicate at high pressures. Science 226, 10711074.

Ringwood, A. E., 1991. Phase transformations and their bearing on the constitution and dynamics of the mantle. Geochem. Cosmochim. Acta 55, 2083-2110.

Ross, M., Boehler, R., Söderlind, P., 2005. Xenon melting curve to $80 \mathrm{GPa}$ and 5p-d hybridization. Phys. Rev. Lett. 95,257801 .

Rubie, D., Tsuchida, Y., Yagi, T., Utsumi, W., Kikegawa, T., Shimomura, O., Brearley, A., 1990. An in situ x ray diffraction study of the kinetics of the $\mathrm{Ni}_{2} \mathrm{SiO}_{4}$ olivine-spinel transformation. J. Geophys. Res. 95, 15829-15844.

Sakai, T., Kondo, T., Ohtani, E., Terasaki, H., Endo, N., Kuba, T., Suzuki, T., Kikegawa, T., 2006. Interaction between iron and post-perovskite at core-mantle boundary and core signature in plume source region. Geophys. Res. Lett. 33, L15317.

Sakamaki, T., Ohtani, E., Urakawa, S., Suzuki, A., Katayama, Y., Zhao, D., 2010. Density of high-Ti basalt magma at high pressure and origin of heterogeneities in the lunar mantle. Earth Planet. Sci. Lett. 299, 285-289.

Sanchez-Valle, C., Martinez, I., Daniel, I., Philippot, P., Bohic, S., Simionovici, A., 2003. Dissolution of strontianite at high P-T conditions: An in-situ synchrotron X-ray fluorescence study. Am. Mineral. 88, 978-985.

Sanloup, C., Fei, Y., 2004. Closure of the Fe-S-Si liquid miscibility gap at high pressures. Phys. Earth Planet. Int. 147, $57-65$.

Sanloup, C., Guyot, F., Gillet, P., Fiquet, G., Hemley, R., Mezouar, M., Martinez, I., 2000a. Structural changes in liquid $\mathrm{Fe}$ at high pressures and high temperatures from synchrotron x-ray diffraction. Europhys. Lett. 52, $151-157$.

Sanloup, C., Guyot, F., Gillet, P., Fiquet, G., Mezouar, M., Martinez, I., 2000b. Density measurements of liquid Fe-S alloys at high-pressure. Geophys. Res. Lett. 27, 811-814.

Sanloup, C., Schmidt, B. C., Perez, E. C., Jambon, A., Gregoryanz, E., Mezouar, M., 2005. Retention of xenon in quartz and Earth's missing xenon. Science 310, 1174-1177.

Secco, R. A., 1995. Viscosity of the outer core. American Geophysical Union, Washington, D.C., pp. $218-226$.

Shannon, M. C., Agee, C. B., 1998. Percolation of core melts at lower mantle conditions. Science 280, 1059-1061.

Shen, A., Keppler, H., 1997. Direct observation of complete miscibility in the albite- $\mathrm{H}_{2} \mathrm{O}$ system. Nature 385, 710712.

Shen, G. Y., Mao, H. K., Hemley, R. J., Duffy, T. S., Rivers, M. L., 1998. Melting and crystal structure of iron at high pressures and temperatures. Geophys. Res. Lett. 25, 373-376.

Shen, Y., Forsyth, D. W., 1995. Geochemical constraints on initial and final depths of melting beneath mid-ocean 
ridges. J. Geophys. Res. 100, 2211-2238.

Sinogeikin, S. V., Bass, J. D., 1999. Single-crystal elasticity of MgO at high pressure. Phys. Rev. B 59, 14141.

Song, T., Helmberger, D., Grand, S. P., 2004. Low-velocity zone atop the 410-km seismic discontinuity in the northwestern United States. Nature 427, 530-533.

Stanley, S., Bloxham, J., 2004. Convective-region geometry as the cause of Uranus' and Neptune's unusual magnetic fields. Nature 428, 151-155.

Stevenson, D. J., 2008. A planetary perspective on the deep Earth. Nature 451, 261-265.

Stewart, A. J., Schmidt, M. W., van Westrenen, W., Liebske, C., 2007. Mars: A new core-crystallization regime. Science 316, 1323-1325.

Stixrude, L., Lithgow-Bertelloni, C., 2011. Thermodynamics of mantle minerals - II. Phase equilibria. Geophys. J. Int. 184 (3), 1180-1213.

Stolper, E., Walker, D., Hager, B. H., Hays, J. F., 1981. Melt segregation from partially molten source regions: the importance of melt density and source region size. J. Geophys. Res. 86, 6261-6271.

Tateno, S., Hirose, K., Ohishi, Y., Tatsumi, Y., 2010. The structure of iron in Earth's inner core. Science 330, 359-361.

Terasaki, H., Kato, T., Urakawa, S., Funakoshi, K., Sato, K., Suzuki, A., Okada, T., 2002. Viscosity change and structural transition of molten Fe at 5 GPa. Geophys. Res. Lett. 29, 68.

Terasaki, H., Suzuki, A., Ohtani, E., Nishida, K., Sakamaki, T., Funakoshi, K., 2006. Effect of pressure on the viscosity of Fe-S and Fe-C liquids up to 16 GPa. Geophys. Res. Lett. 33, L22307.

Usselman, T. M., 1975. Experimental approach to the state of the core: Part I. The liquidus relations of the Fe-rich portion of the Fe-Ni-S system from 30 to $100 \mathrm{~kb}$. Am. J. Sci. 275, 278-290.

Wang, Y. B., Uchida, T., Westferro, F., Rivers, M., Nishiyama, N., Gebhardt, J., Lesher, C., Sutton, S., 2005. Highpressure x-ray tomography microscope: Synchrotron computed microtomography at high pressure and temperature. Rev. Scientific Instrum. 76,073709.

Weber, R. C., Lin, P.-Y., Garnero, E. J., Williams, Q., Lognonné, P., 2011. Seismic detection of the lunar core. Science $331,309-312$.

Wenk, H. R. (Ed.), 2006. Neutron Scattering in Earth Sciences, Reviews in Mineralogy and Geochemistry 63. Mineral. Soc. America.

Williams, Q., Garnero, E. J., 1996. Seismic evidence for partial melt at the base of Earth's mantle. Science 273, 1528-1530.

Yoshino, T., Walter, M. J., Katsura, T., 2003. Core formation in planetesimals triggered by permeable flow. Nature $422,154-158$. 

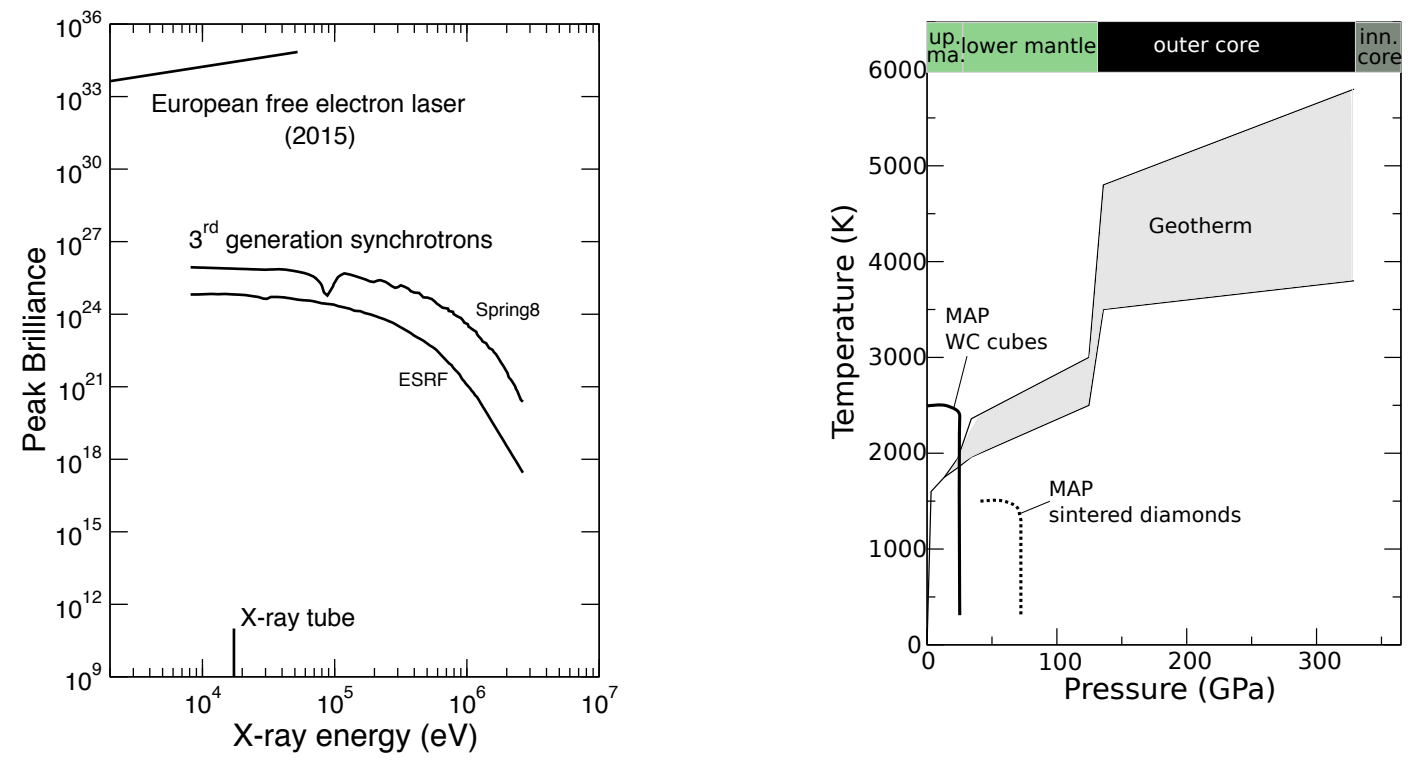

Figure 1: Left: Brilliance of X-ray radiation; unity is the number of photons per second per $\operatorname{mrad}^{2}$ and per $0.1 \%$ bandwidth. Right: P-T conditions within Earth interiors compared with the experimental P-T conditions generated using multi-anvil presses ('WC' stands for tungsten carbide, the most commonly used material for anvils).

Figure 1: Gauche: Brilliance du rayonnement X; l'unité est le nombre de photons par seconde et par mrad ${ }^{2}$ et par 0,1\% de bande passante. Droite: conditions P-T de l'intérieur de la Terre et conditions P-T générées expérimentalement en presse multi-enclumes. La cellule-diamant combinée au chauffage laser permet de reproduire l'ensemble des conditions terrestres. 


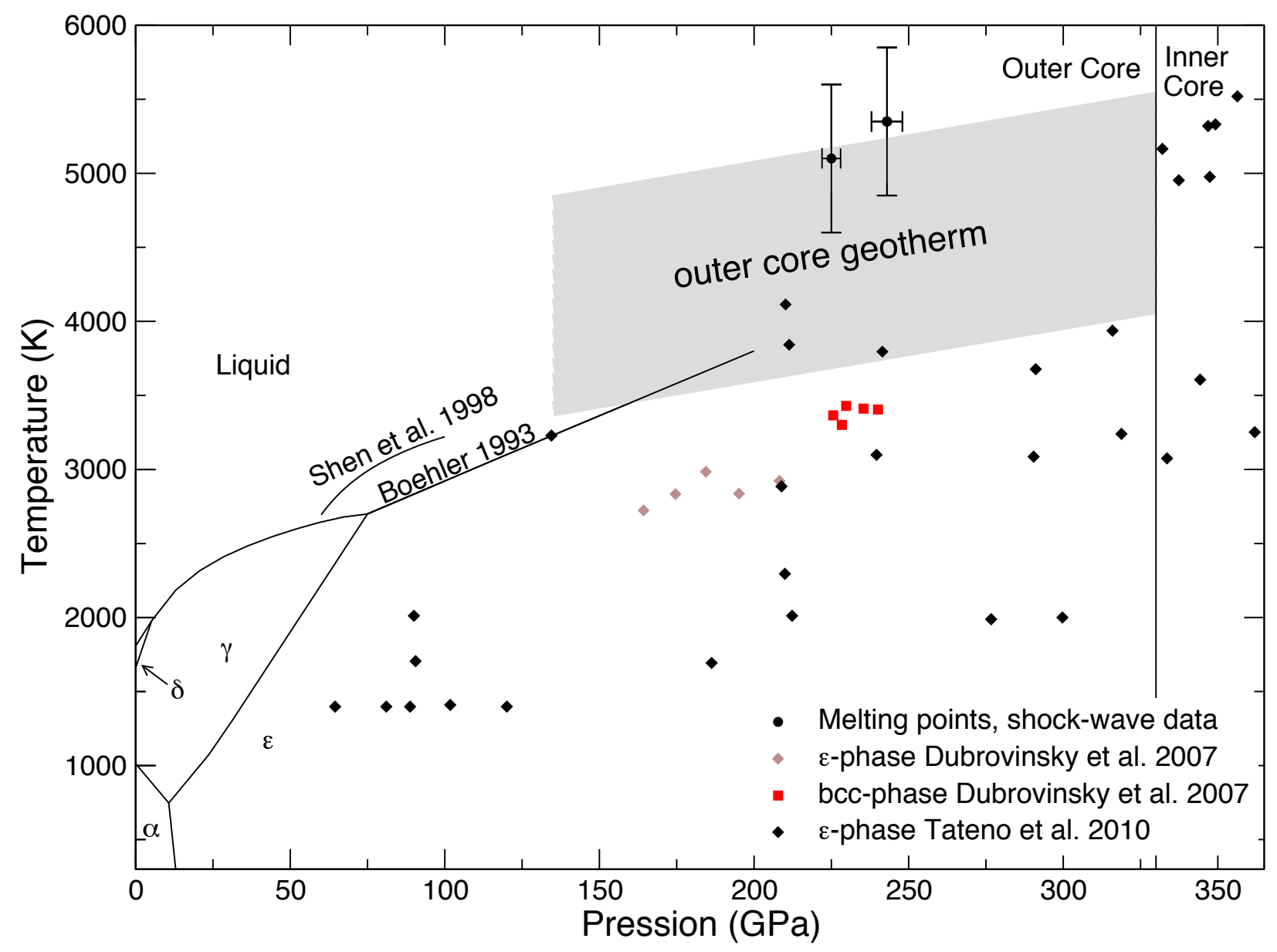

Figure 2: Phase diagram of iron determined from high P-T experiments, either using laser-heated diamond anvil cells (Boehler, 1993; Shen et al., 1998; Dubrovinsky et al., 2007; Tateno et al., 2010) or shock-wave experiments (Brown and McQueen, 1986; Nguyen and Holmes, 2004). $\alpha$-Fe and $\delta$-Fe have a body-cubic centered cell, $\gamma$-Fe has a facecubic centered cell, and $\epsilon$-Fe a hexagonal close-packed cell.

Figure 2: Diagramme de phase du fer déterminé à partir de résultats d'expériences en cellule-diamant/chauffage laser (Boehler, 1993; Shen et al., 1998; Dubrovinsky et al., 2007; Tateno et al., 2010) et d'expériences de choc (Brown and McQueen, 1986; Nguyen and Holmes, 2004). 

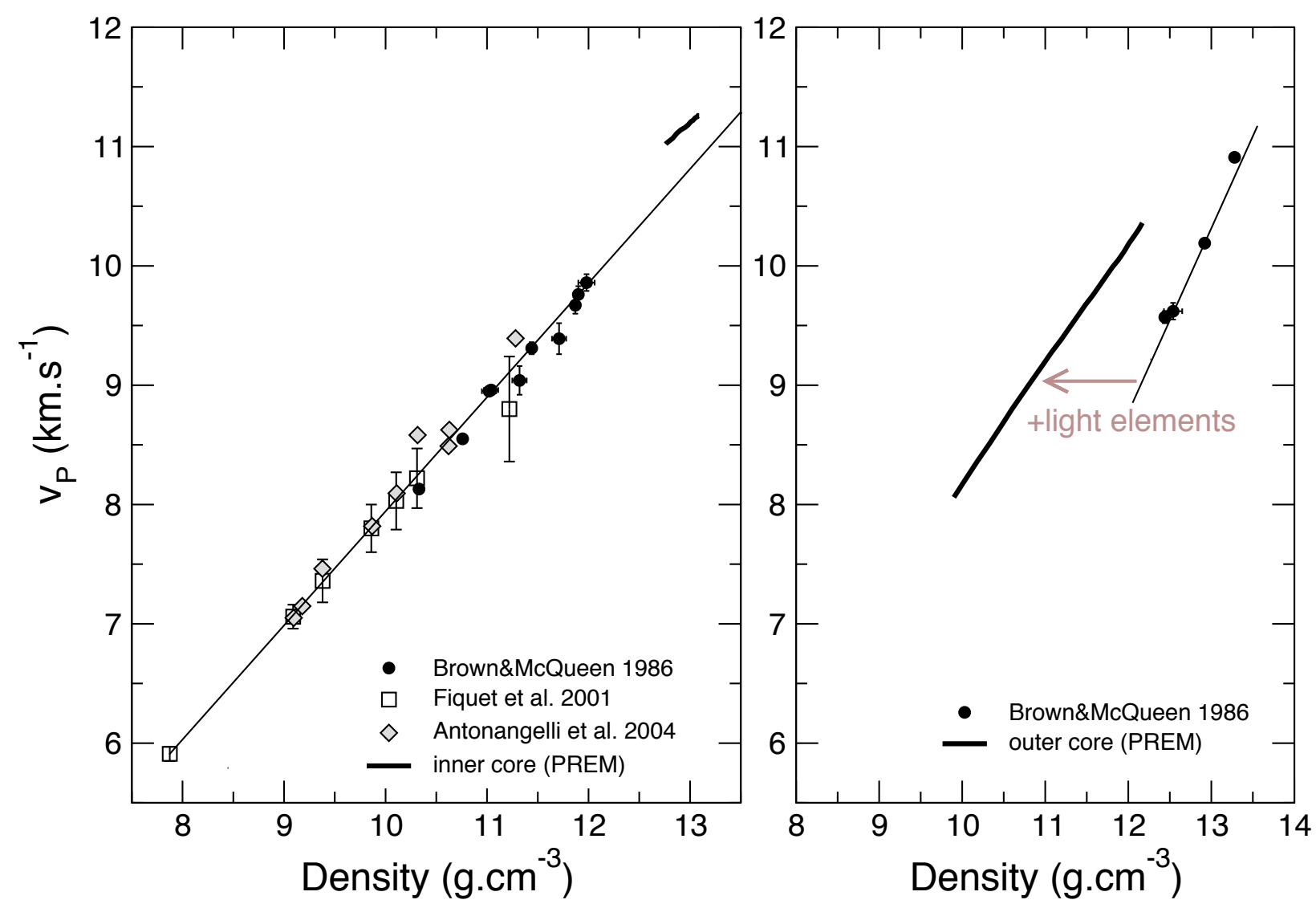

Figure 3: Compressional velocity $\left(\mathrm{V}_{P}\right)$ as a function of density in solid $\mathrm{Fe}$ (left) and liquid $\mathrm{Fe}$ (right) measured experimentally using shock-wave techniques at high T (Brown and McQueen, 1986) and inelastic X-ray scattering techniques at room T (Fiquet et al., 2001; Antonangeli et al., 2004). PREM seismic profiles are shown for comparison (Dziewonski and Anderson, 1981).

Figure 3: Vitesse des ondes de compression en fonction de la densité pour le fer solide (gauche) et liquide (droite) mesurée expérimentalement lors d'expériences de choc à haute T (Brown and McQueen, 1986) et par diffusion inélastique des rayons X à T ambiante (Fiquet et al., 2001; Antonangeli et al., 2004). Les profils sismiques du modèle PREM sont donnés pour comparaison (Dziewonski and Anderson, 1981). 
$2 \mathrm{GPa}-1830 \mathrm{~K}$ Solid

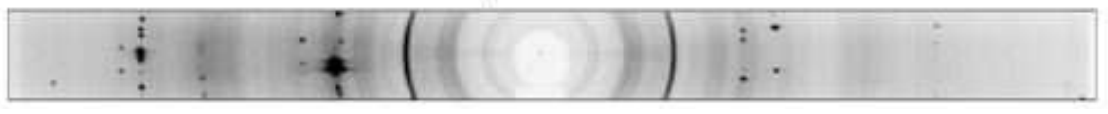

$2 \mathrm{GPa}-2300 \mathrm{~K}$ Molten

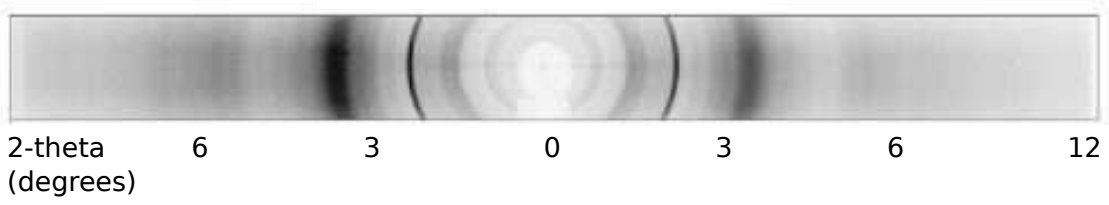

Figure 4: Identifying melting at high P: the spotty diffraction rings from crystalline $\mathrm{Fe}$ (top) disappear upon melting and an X-ray diffuse scattering appears (bottom). The continuous rings in both upper and lower panels at small angles are contributions from the gasket and sample container. The Fe sample was compressed at $2 \mathrm{GPa}$ in a large volume press (Sanloup et al., 2000a).

Figure 4: Critère de fusion à haute P: apparition d'un signal X diffus (bas) au lieu de pics de diffraction (haut). L'échantillon de fer était comprimé à 2 GPa dans une presse gros volume (Sanloup et al., 2000a). 

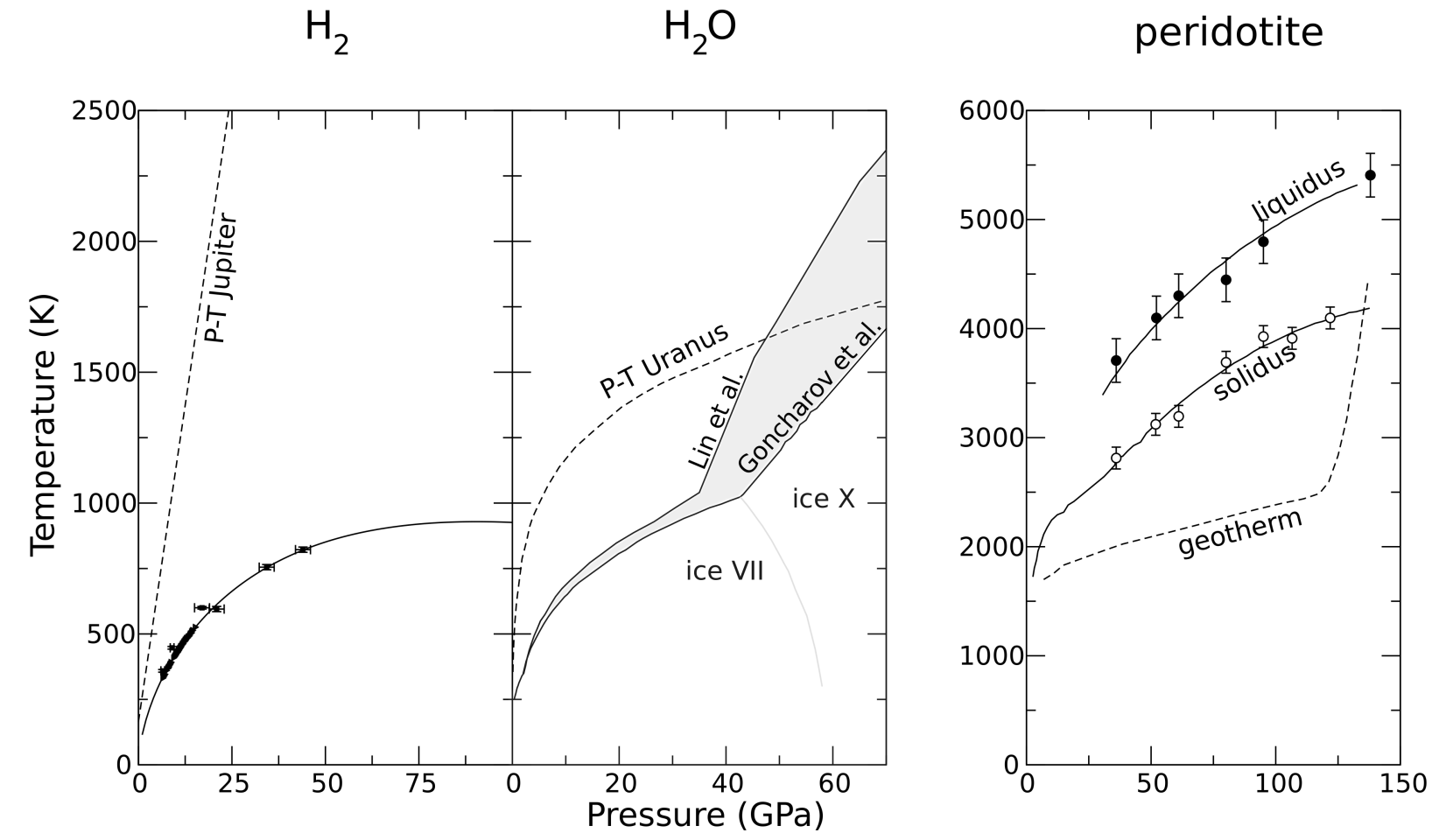

Figure 5: Melting curves of major planetary materials: $\mathrm{H}_{2}$ (data from Datchi et al. (2000); Gregoryanz et al. (2003)), $\mathrm{H}_{2} \mathrm{O}$ (data from Lin et al. (2005a); Goncharov et al. (2009)), and peridotite (Fiquet et al., 2010).

Figure 5: Courbe de fusion de matériaux planétaires majeurs: $H_{2}$ (données de Datchi et al. (2000); Gregoryanz et al. (2003)), $\mathrm{H}_{2} \mathrm{O}$ (données de Lin et al. (2005a); Goncharov et al. (2009)), et péridotite (Fiquet et al., 2010). 


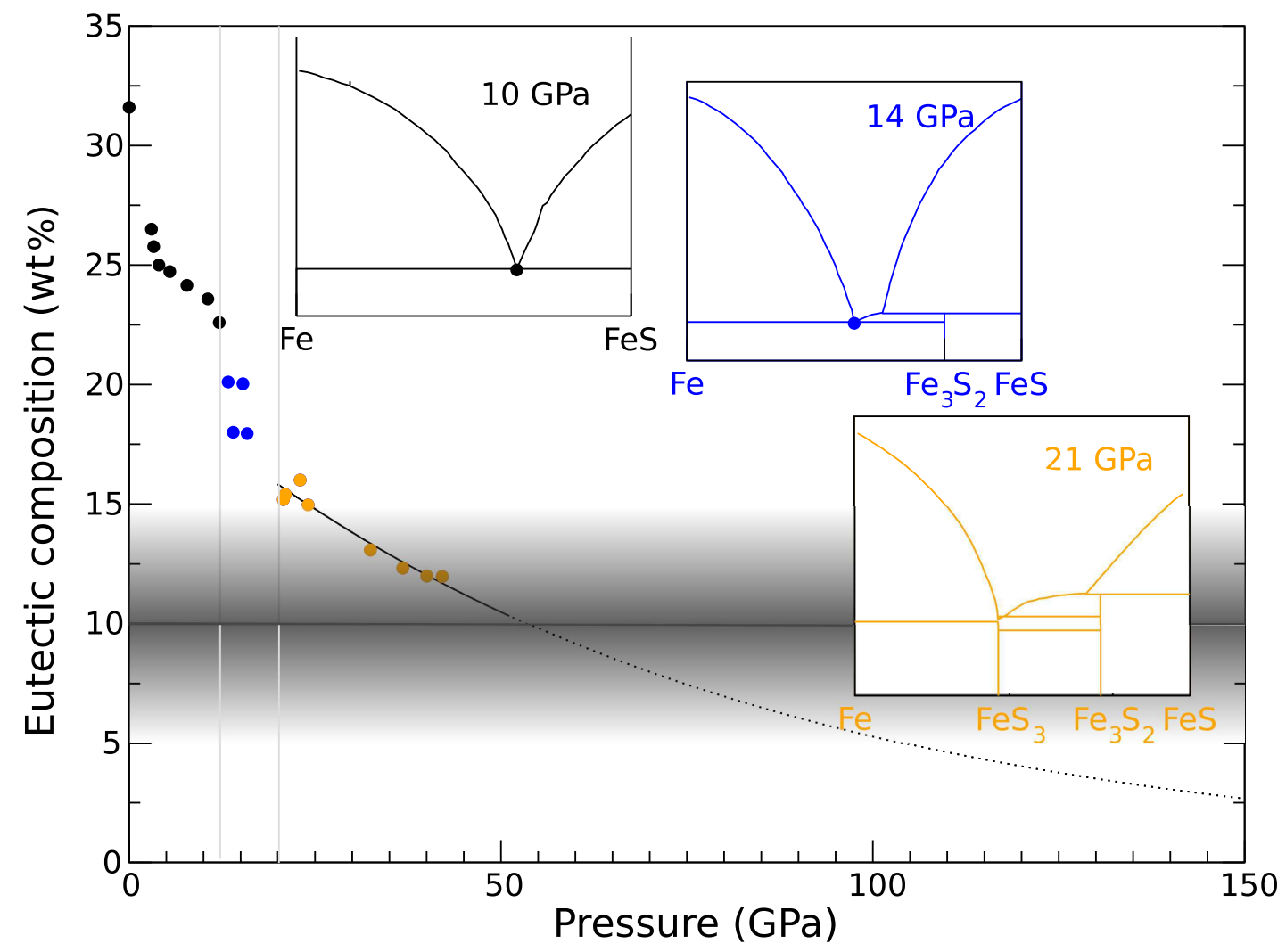

Figure 6: Pressure evolution of the eutectic composition in the Fe-FeS system; data are from Morard et al. (2007); Usselman (1975); Stewart et al. (2007); Chudinovskikh and Boehler (2007), the shaded area indicate the total content of light elements in the outer core $(10 \pm 5 \%)$. Insets: Fe-FeS phase diagram typical of each pressure interval (adapted from Fei et al. $(1997,2000))$.

Figure 6: Composition eutectique du système Fe-FeS en fonction de la pression; données de Morard et al. (2007); Usselman (1975); Stewart et al. (2007); Chudinovskikh and Boehler (2007), la zone ombrée indique la teneur en

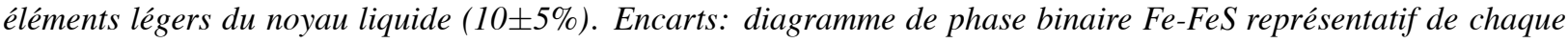
intervalle de pression (adapté de Fei et al. $(1997,2000)$ ). 

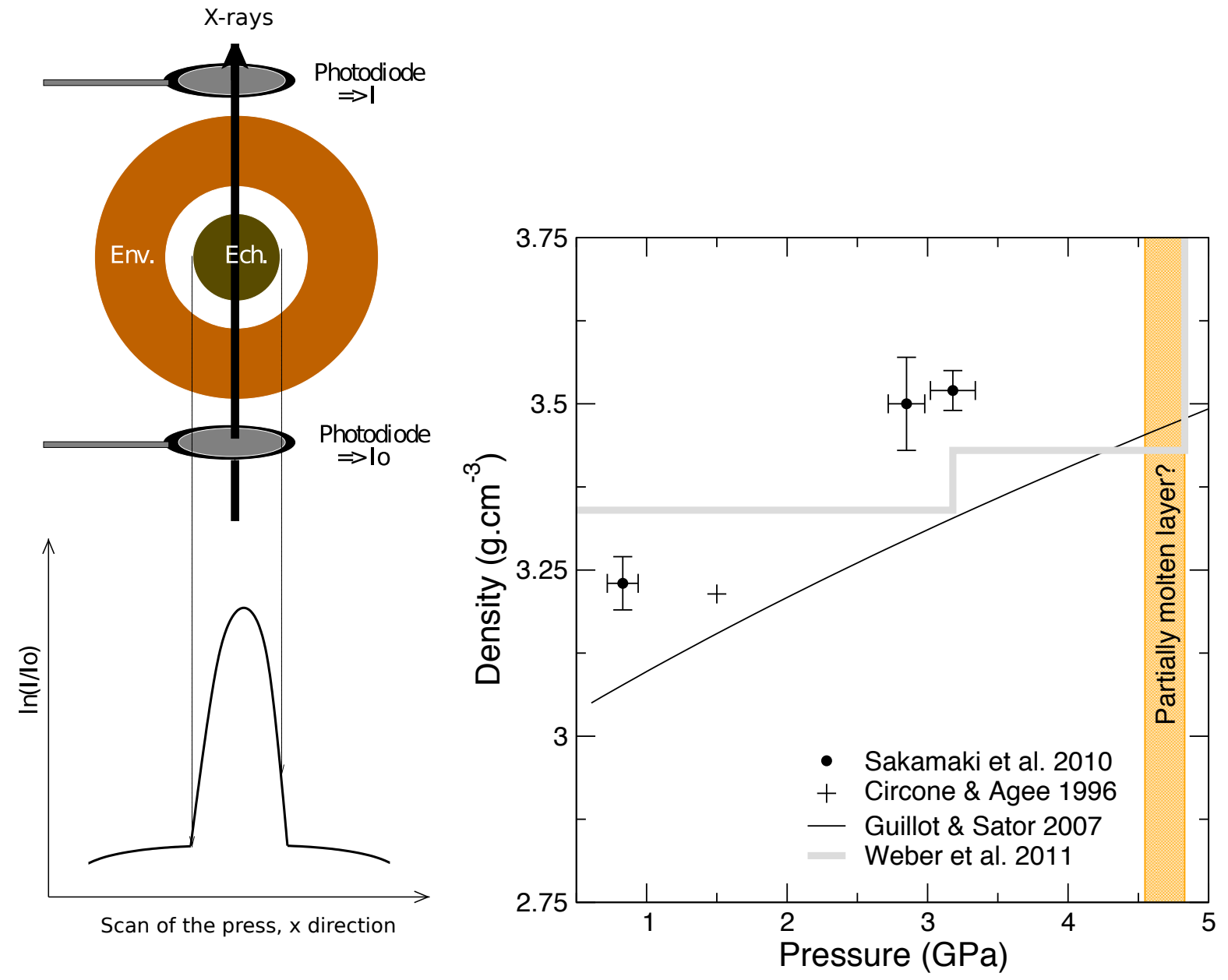

Figure 7: Left: sketch of the X-ray absorption technique, the intensity ratio $\mathrm{I} / \mathrm{I}_{0}$ obeys the Beer-Lambert law. Right: Density of molten lunar high-Ti basalts (BG14) as a function of pressure. Experimental data are from Sakamaki et al. (2010) and Circone and Agee (1996), theoretical data are from Guillot and Sator (2007) (solid curve). All data are corrected to a common T of $1800 \mathrm{~K}$. Seismological density profile is given (grey line) for comparison (Weber et al., 2011).

Figure 7: Gauche: schéma de la technique de mesure de densité par absorption des rayons X; le rapport d'intensité, I/I $I_{0}$, obéit la loi de Beer-Lambert. Droite: densité du basalte lunaire riche en Ti (BG14) en fonction de la pression. Les données expérimentales sont de Sakamaki et al. (2010) et Circone and Agee (1996), les calculs théoriques sont de Guillot and Sator (2007) (courbe pleine). Tous les points ont été ramenés sur l'isotherme $1800 \mathrm{~K}$. Le profil de densité sismologique est donné (courbe grise) pour comparaison (Weber et al., 2011). 

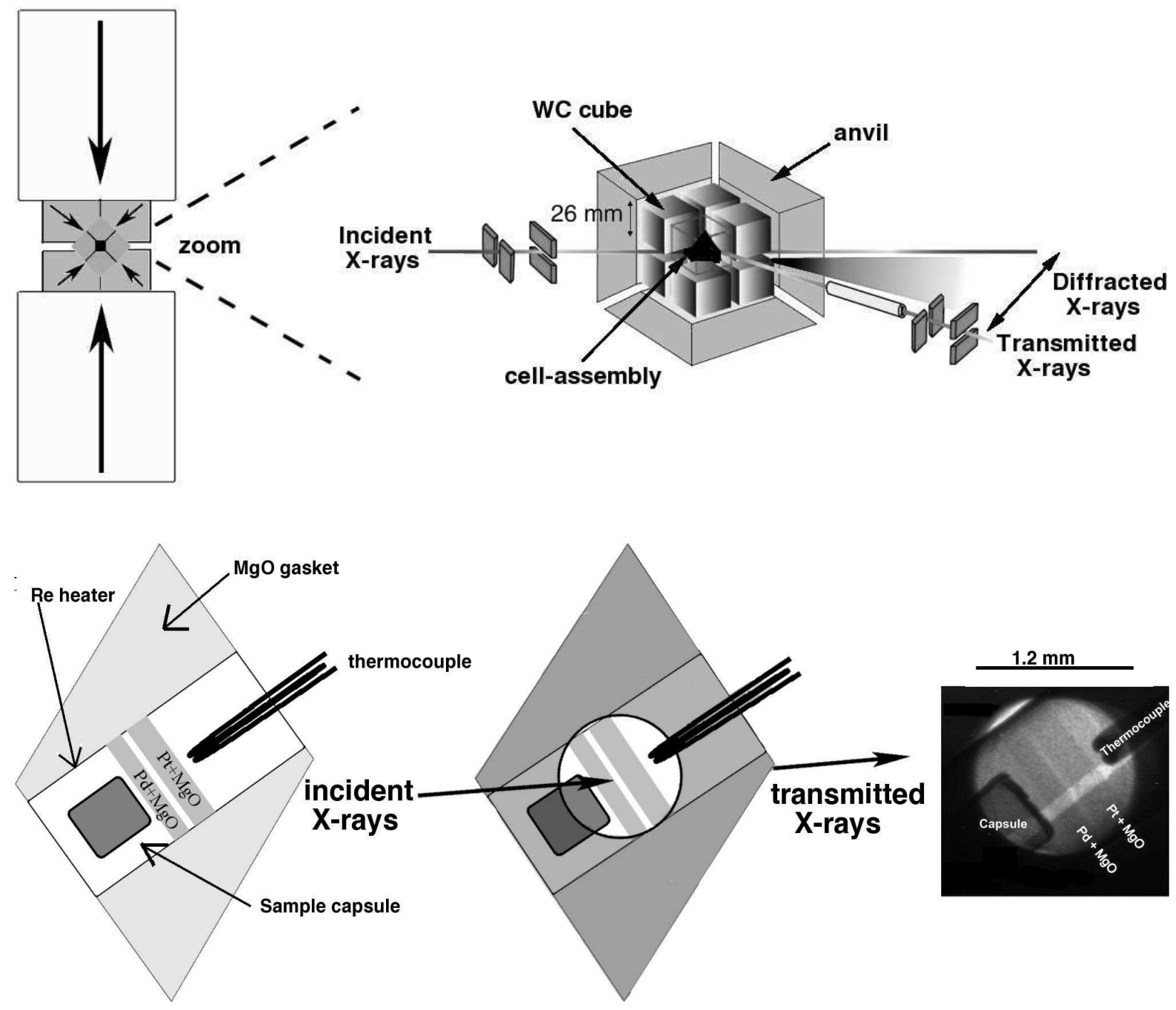

Figure 8: Top: X-ray imaging and diffraction set-up for in situ high P-T measurements using a multi-anvil press (on the left). Bottom: schematics of 2-D imaging using the transmitted X-rays; the whole cell-assembly is drawn, low Z materials (BN, diamond window) are inserted in the cell-assembly along the X-ray path and define a window on the sample. Translated from Dewaele and Sanloup (2005).

Figure 8: Haut: principes de l'imagerie par radiographie X à hautes $P$-T en presse multi-enclumes (à gauche). Bas: schéma de l'assemblage expérimental utilisé et image de radiographie X obtenue à partir du passage du faisceau X incident à travers une fenêtre au sein de l'assemblage (Spring-8, Japon). 


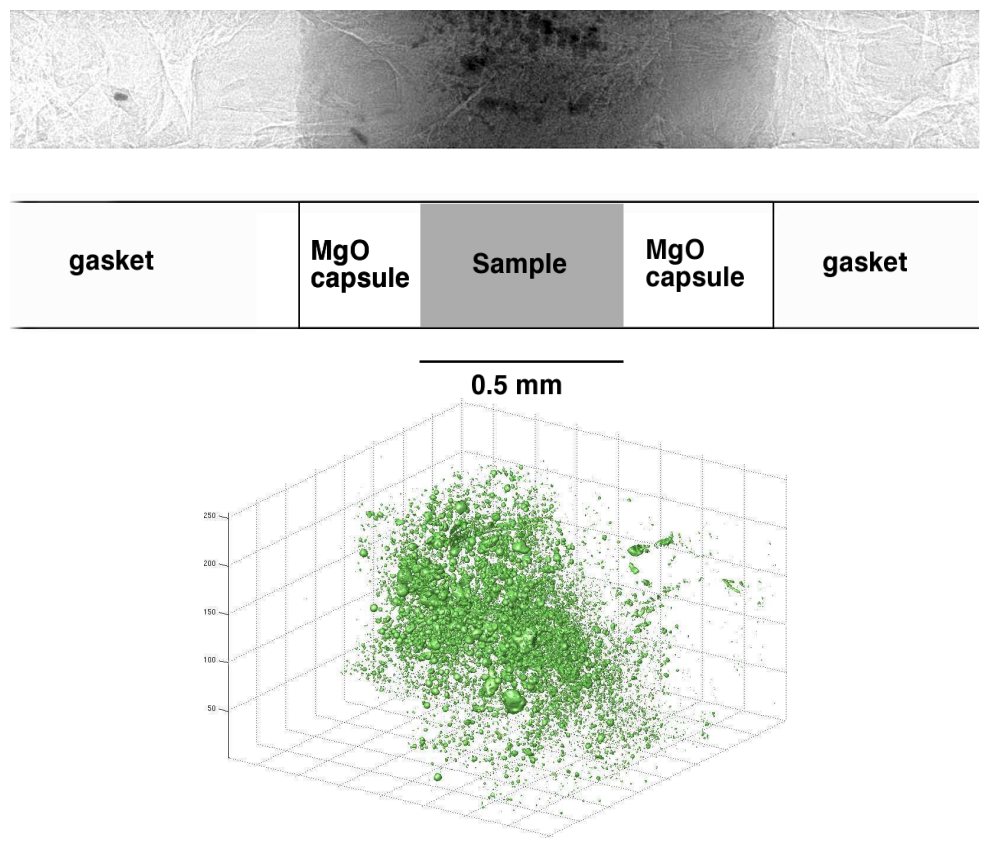

Figure 9: Top: 2-D X-ray radiograph of an olivine+Fe-FeS melt sample at $2 \mathrm{GPa}$ and $1500 \mathrm{~K}$; the height of the image is defined by the gap between the anvils ( $\sim 300 \mu \mathrm{m}$ at $2 \mathrm{GPa}$ ). N.B.: the graphite furnace surrounding the $\mathrm{MgO}$ capsule is not distinguishable from the boron-epoxy gasket, having a similar X-ray absorption contrast. Bottom: 3-D reconstruction of the Fe-FeS melt pockets in the olivine matrix, the vertical axis indicates the distance in microns. Courtesy of G. Morard.

Figure 9: Haut: radiographie X 2-D d'un échantillon olivine+Fe-FeS fondu à 2 GPa et $1500 \mathrm{~K}$; l'hauteur de l'image est définie par l'espace entre les enclumes ( $300 \mu \mathrm{m}$ à $2 \mathrm{GPa})$. N.B.: le four en graphite autour de la capsule en $\mathrm{MgO}$ n'est pas distinguable du joint en bore-epoxy car ces matériaux ont le même contraste d'absorption. Bas: reconstruction 3-D des poches de Fe-FeS liquide dans la matrice d'olivine, l'axe vertical donne la distance en microns. Crédit: G. Morard. 


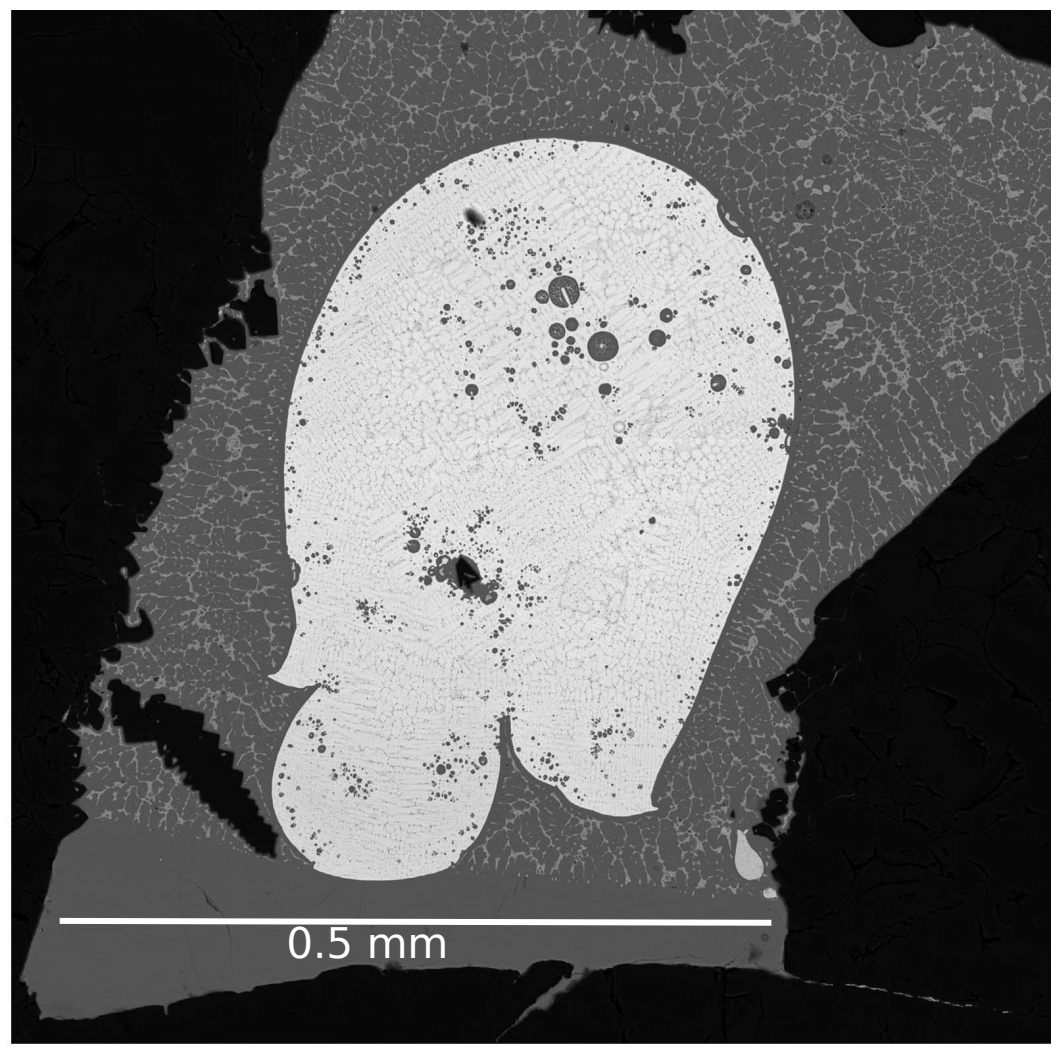

Figure 10: Back-scattered electron image of a Fe-FeO sample quenched from $25 \mathrm{GPa}$ and $2500 \mathrm{~K}$; the sample is surrounded by an $\mathrm{Al}_{2} \mathrm{O}_{3}$ capsule. Lighter areas: Fe-rich melt, grey areas: FeO-rich melt.

Figure 10: Image en microscopie électronique à balayage d'un échantillon Fe-FeO porté à 25 GPa-2500 K puis trempé; l'échantillon est entouré d'une capsule en $\mathrm{Al}_{2} \mathrm{O}_{3}$. Zones gris claires: Fe liquide, zones plus foncées: FeO liquide. 
Fe-S-C melts

Fe-S-Si melts
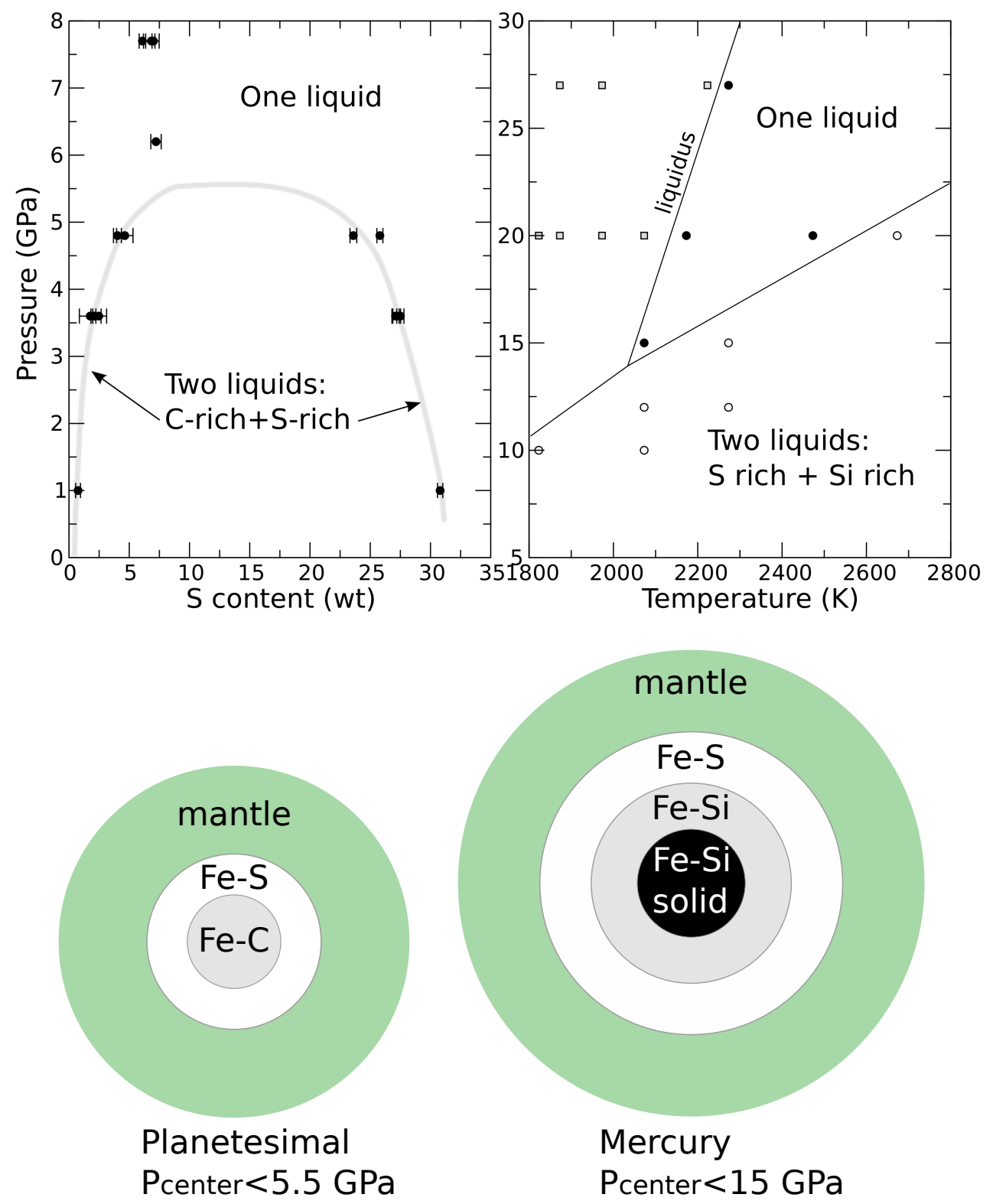

Figure 11: Top: mapping of the miscibility fields of Fe-S-C melts (left, adapted from Corgne et al. (2008), T range: $1750-2200^{\circ} \mathrm{C}$ ) and the Fe-S-Si melt (right, data from Sanloup and Fei (2004) and Malavergne et al. (2007)). Bottom: models of planetary interiors for a planetesimal (left) and for Mercury (right, adapted from Malavergne et al. (2010)). Figure 11: Haut: Lacunes de miscibilité dans les liquides Fe-S-C (gauche, adapté de Corgne et al. (2008), domaine de T: $1750-2200^{\circ} \mathrm{C}$ ) et Fe-S-Si (droite, données de Sanloup and Fei (2004) et Malavergne et al. (2007)). Bas: modèles d'intérieur planétaire pour un planétésimal (gauche) et pour Mercure (droite, adapté de Malavergne et al. (2010)). 


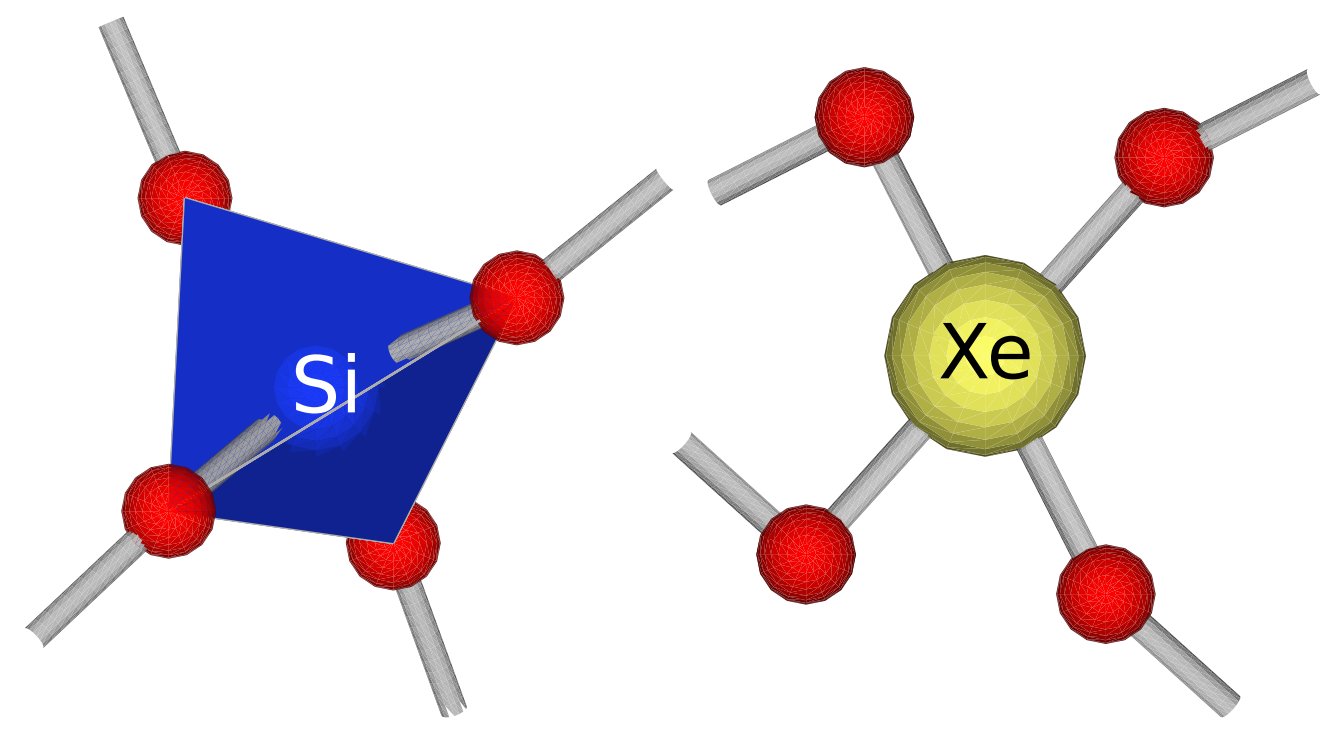

Figure 12: $\mathrm{SiO}_{4}$ tetraedra in high $\mathrm{T} \beta$-quartz (left) and Xe substitution (right).

Figure 12: Tétraèdres $\mathrm{SiO}_{4}$ dans la phase haute $\mathrm{T}$ du quartz (gauche) et substitution de l'atome de Si par un atome de Xe (droite). 